\title{
No Relief: Tax Prices and Property Tax Burdens
}

\author{
Nathan B. Anderson * \\ 03.26.2011 \\ JEL CODES: H71, H72 \\ Keywords: Tax Price; Property Tax \\ Contact Information: \\ nbanderson78@gmail.com
}

\footnotetext{
*Thank you to Erik Byro for excellent research assistance. Thank you to John DiNardo, Jane Dokko, Bob Kaestner, Brian Knight, Dave Merriman, Dan McMillen, and seminar participants at the NBER Summer Institute, DePaul University, and the National Tax Association Annual Meeting. I owe a debt of gratitude to several anonymous referees that made detailed and thoughtful comments.
} 


\title{
No Relief: Tax Prices and Property Tax Burdens
}

\begin{abstract}
In 2001 the state of Minnesota reduced the weights assigned to non-residential property in local property tax bases, which increased residents' price of raising property tax revenue and affords the opportunity to identify the tax price elasticity of local tax revenues and expenditures. Results suggest that a one percent increase in residents' tax prices is associated with a one percent decrease in per-resident property tax revenues as well as a substantial reduction in capital expenditures. The unit price elasticity of property tax revenues suggests that popular tax relief programs that reduce residents' tax prices - homestead exemptions - do not reduce homeowners' tax payments.
\end{abstract}

This paper estimates an important parameter in local public finance - the tax price elasticity of local government revenues and expenditures - using a policy innovation in Minnesota that creates large and unanticipated within-city changes in property tax base composition. The policy innovation alters the definition of local tax base, decreasing the share of commercial-industrial property in the tax base and thus increasing the share of city property taxes paid by residential property owners. An individual property owner's tax price of property tax revenue is equal to the incremental tax the individual must pay in order to increase total property tax revenue by one dollar. Thus, the policy change increased the tax prices of residential taxpayers by increasing their share of the tax burden and decreased the tax prices of commercial-industrial taxpayers by decreasing their share of the tax burden. The exogenous tax price variation created by the policy change allows regressions to produce precise causal estimates of the tax price elasticity of tax revenues and expenditures. Regression results demonstrate that the tax price elasticity of property tax revenues is approximately negative one, which implies that a one percent increase in tax price is offset by a one percent decrease in total property tax revenues. The regression results also suggest that capital expenditures are responsive to tax price changes, while current expenditures are not.

The focus of this paper is the estimation of the tax price elasticity of property tax revenues. The vast majority of prior work estimates only the tax price elasticity of expenditures. Focusing on the response of property tax revenues to tax price changes is important in and of itself because the tax price elasticity of property tax revenue provides direct evidence on the effectiveness of state and federal government programs purported to provide property tax relief via tax price reductions.

The most widespread program purported to provide tax relief to homeowners is the homestead exemption. All 50 states offer property tax exemptions available exclusively to some or all homeowners. 17 Most homestead exemptions reduce homeowners' tax prices by altering the composition

\footnotetext{
${ }^{1}$ Most homestead exemption programs are available without regard to income. Twenty-eight states make the exemptions available to all homeowners, rather than only a subset of homeowners (e.g., seniors, veterans, low income). See Baer (1998) and Baer (2003).
} 
of the property tax base. Other popular programs also reduce tax prices for a subset of taxpayers, including matching grants from state and federal governments, revenue sharing, assessment limitations, and the deductibility of property taxes on federal income taxes.

Estimating the tax price elasticity of property tax revenues is important because the behavioral responses of policy makers and residents to reduced tax prices could result in either lower or higher property tax burdens. Behavioral responses to reduced tax prices produce one of three broad outcomes for residents: pay less in taxes but maintain the same expenditures; pay the same in taxes and increase expenditures a little; or pay more in taxes and increase expenditures by a lot. The tax price elasticity estimates presented in this paper provide valuable insight into the impact of all of these programs on local governments and local taxpayers. For example, President George W. Bush's Advisory Panel on Federal Tax Reform proposed eliminating the federal tax deduction for local taxes - a policy which would significantly increase local residents' tax prices across the US. The lack of any variation in local tax deductibility (it applies throughout the US) makes it extremely difficult to directly estimate the impact of such a change. The estimates in this paper, however, can be used to assess the impact of the proposed change.

Despite the prevalence of homestead exemptions, virtually nothing is known about their effects on property tax burdens and local public expenditures. Previous work has focused on estimating the tax price elasticity of expenditures. These estimates, however, are likely biased because of the endogenous tax price variation in cross-sectional data. Panel data - by controlling for betweencity differences in unobservables like local preferences and costs - provide the opportunity to eliminate the bias in inherent in cross-sectional estimates..$^{2}$ Yet researchers hoping to identify the tax price elasticity via the within-city tax price variation observed in panel data have been stymied by two important problems: that within-city changes in tax prices are too small to produce precise estimates and that any observed within-city changes in tax prices are likely endogenous.

The Minnesota policy change overcomes these two problems because it produced large, unanticipated, and arguably exogenous within-city changes in tax prices. The tax price elasticity estimates derived from this natural experiment imply that, because of the behavioral response of local governments, homestead exemptions provide no tax relief; instead the tax price reductions produce, on average, identical residential tax bills, increased property tax revenue, and increased public expenditures.

\footnotetext{
${ }^{2}$ The dependent variable in these studies is most often expenditure on a particular service or group of services such as education (Feldstein (1975) and Ladd (1975)), and general expenditures, police, and parks and recreation (Bergstrom and Goodman (1973)). Feldstein and Metcalf (1987) examine the effects of federal tax deductibility on revenues and Holtz-Eakin and Rosen (1990), using panel data, examine the effects of federal deductibility on local property tax rates. Inman (1989) examines residential tax shares and property tax revenues and is an additional example a panel study. Inman (1979) reviews community level studies and Rubinfeld (1987) reviews studies using individual level data. For a review of studies outside of the United States and a discussion of various methods of identifying the decisive voter, see Ross and Yinger (1999).
} 
Further, one of the primary causes of between-city differences in resident's tax prices is betweencity differences in the composition of the property tax base caused by the non-uniform distribution of non-residential property across cities. Because Minnesota's policy change alters the composition of the property tax base, the estimates can also be used to produced unbiased estimates of the effects of the between-city distribution of non-residential property on local revenues and expenditures.

Two other recent papers also estimate tax price elasticities of demand using panel data along with arguably exogenous changes in voters' tax prices. First, Anderson (2006) examines city revenues and expenditures and, like this current paper, uses variation in the composition of the property tax base to identify price elasticities of revenues and expenditures. The within-city variation in tax prices in Anderson (2006), however, is a result of changes in the taxation of vacation homes, which limits its external validity because relatively few jurisdictions have a significant concentration of vacation homes and those jurisdictions are fundamentally different than other jurisdictions. In Minnesota only 1 in 20 cities derive more than two percent of their property tax base from vacation homes. Cities with at least $2 \%$ of their tax base in vacation homes are much smaller than other cities - none have population greater than 7,500 - and they have very high levels of per capita public expenditures - on average $50 \%$ higher - than other cities. In contrast, this paper's results are widely applicable because it uses changes in the taxation of commercial-industrial property, whose presence is ubiquitous across cities. In Minnesota, more than $90 \%$ of cities have at least $10 \%$ of their property tax base derived from commercial-industrial property $!^{3}$

Second, Rockoff (2010) uses New York state administrative panel data to examine school districts' current expenditures and estimates a tax price elasticity of current school district expenditures of approximately -0.18 , which is in line with previous estimates. A state-funded homestead exemption program in New York (NYSTAR) creates within-school district variation in residents' tax prices. The main effect of funded programs like NYSTAR is to change the tax prices of residential properties; because it is state-funded NYSTAR does not change the tax prices of those who do not receive the exemption (e.g., commercial-industrial property owners). $4^{4}$ Only 15 states have homestead exemptions similar to New York's. Homestead exemptions in the other 35 states are not funded and thus they change homeowners' tax prices by changing the tax prices of nonhomeowners. As noted above, the policy change in Minnesota resembles the typical homestead exemption policy because it also shifts the marginal tax burden across property types. This makes the results here widely applicable.

\footnotetext{
${ }^{3}$ For cities in Minnesota, commercial-industrial property represents about one-quarter of the tax base for the average city and a nearly $60 \%$ of all non-homestead property. Vacation homes represent on average less than $1 \%$ of cities' property tax base and only approximately $3 \%$ of the total housing stock in the United States (U.S. census 2000).

${ }^{4}$ For details on the STAR school district exemption in New York, which does not reduce local tax base, see The Municipal Tax Base: A guide for local officials, NYS Office of Real Property Services, March 2008.
} 
Finally, this paper estimates the tax price elasticity of cities' decisions on revenues and expenditures, rather than school districts or townships, because in Minnesota cities are the most numerous type of fiscally independent local government with substantial populations 5 Strong restrictions on school districts' access to property tax base makes them unsuitable for an analysis of local governments' response to changes in tax prices because any response is mechanical rather than behavioral. Property taxes are the main independent source of financing cities' expenditures and cities enjoy relatively broad access to their property tax base and thus their governments have a large amount of leeway in making decisions on revenue and expenditure. Estimation using city governments is widely applicable since these governments are widespread across the United States.

\section{Tax Prices and Local Revenues and Expenditures}

Property tax revenue in city $j$ equals the product of the tax rate $(\tau)$ and the total tax base $(B)$ plus any matching grant revenue from the state,

$$
R_{j t}=\tau_{j t} B_{j t}+\psi_{j t} \tau_{j t} B_{j t}
$$

where $\psi_{j t} \in[0,1]$ is the matching rate from the state government. Unlike sales and income taxes, the property tax base is known by policy makers ex ante, so the city's uniform property tax rate falls out as the ratio of the city's desired revenues to the city's total tax base. Because a city government's decision variable is its revenue request, in practice the tax rates implied by these revenue requests change almost every year. As Bogart and Bradford (1990) emphasize, the relative ease and flexibility of setting property tax revenues means that property tax revenues finance marginal public expenditures because they can be set to cover the difference between desired expenditures and the less easily manipulable non-property tax revenues.

When property taxes finance cities' marginal changes in expenditure, a resident's tax price reflects the cost of raising additional per-resident property tax revenues and the cost of additional public expenditures. It can be shown, via an accounting identity, that the five components of a resident $i$ 's tax price are the marginal cost of public service quality, the homestead ratio, the homestead tax share, the matching rate, and federal tax deductibility.

$$
\pi_{i j t}=c_{j t} \times H R_{i j t} \times H S_{j t} \times\left(1-M_{j t}\right) \times\left(1-\tau_{i t}\right)
$$

The per-resident marginal cost, assumed to equal average cost, of an additional unit of public service quality equals $c_{j t}$. The ratio of the tax base of voter $i$ to the per-resident homestead tax base

\footnotetext{
${ }^{5}$ The majority of townships have population less than 500 have very small and volatile tax revenues and expenditures, making it difficult to produce precise estimates.
} 
in city $j$ is voter $i$ 's homestead ratio, $H R_{i j t}$. The share of total tax base derived from homestead property in city $j$ is the city's homestead tax share, $H S_{j t}$. The next component of tax price, $M_{j t}=1 /\left(1+\psi_{j t}\right)$, is the state-financed share of locally raised revenues. The last component of tax price $\left(1-\tau_{i t}\right)$ is the effect of federal tax deductibility for a taxpayer facing a marginal tax rate $\tau_{i t}$ who has not reached the deduction limit. At any given time, only the homestead ratio $\left(H R_{i j t}\right)$ and federal tax deductibility $\left(\left(1-\tau_{i t}\right)\right)$ cause tax prices to vary between a city's residents. When a median voter is decisive, it is his or her federal marginal tax rate and homestead ratio that will determine public service demand. ${ }^{6}$

Residents' tax prices vary across cities because these five components vary across cities. Differences in the composition of the tax base and other community characteristics affect marginal cost. For example, commercial-industrial property could place a higher burden on city infrastructure by increasing maintenance and public safety costs. Cities with higher poverty and unemployment rates may face higher costs of providing the same level of public safety.7 A median voter's homestead ratio in city $j$ may be lower when the distribution of housing values is right-skewed. The homestead tax share varies across cities because some cities have more non-residential property than others. These differences arise because of a combination of historical accidents, zoning policies, and sorting across cities caused by differences in taxes and public service quality. Cities, like nations, can be tax havens, lowering taxes to encourage business location and investment.

Marginal costs, homestead ratios, and homestead shares also change within a city over time. Costs change when community characteristics change or because of inflation. Homestead ratios and tax shares change because of the addition of new properties, the destruction of old properties, and changes in the value of existing properties. Homestead tax share increases when a city's residential properties appreciate faster than its commercial properties. Differing rates of appreciation are common within cities and may be caused by shifts in demand, changes to neighborhood amenities, and tax and expenditure changes 8

Government policies affect tax prices within and across cities by redefining the tax base and thus altering its composition. The most popular form of so-called property tax relief, the unfunded homestead exemption, exempts some amount $\$ X>0$ of a property's value from taxation, thereby changing homestead tax shares and homestead ratios. Consider a city with two types of taxpayers, homeowners and business owners. There are 10 rich homeowners owning property with a taxable value of $\$ 100,000$ each, 10 poor homeowners with taxable values of $\$ 50,000$ each, and the total value of all business property is $\$ 500,000$. Suppose the city wants to raise $\$ 1$ million in revenues.

\footnotetext{
${ }^{6}$ The tax price equals $\pi$ if voters are myopic in that they assume that tax prices are fixed. See Crane (1990) and Wildasin (1989) for discussion of tax price with non-myopic voters.

${ }^{7}$ See Bradford, Malt, and Oates (1969).

${ }^{8}$ See Case and Shiller (1989), Case and Mayer (1996), McMillen (2003), and Guerrieri, Hartley, and Hurst (2010) for evidence and examples.
} 
The homestead tax share is 0.75 so homeowners will pay $\$ 750,000$ of total revenues 9 Assuming per-resident marginal cost equals one implies that a rich voter's tax price equals 1 and a poor voter's tax price equals 0.5 .10 The introduction of a $\$ 20,000$ homestead exemption reduces homestead tax share to 0.69 , maintains the rich voter's tax price at 1 , and decreases the poor voter's tax price to 0.38 . That is, the tax price effects of the $\$ 20,000$ homestead exemption vary by initial homestead taxable value. The $\$ 20,000$ homestead exemption causes business properties' tax share, the share of revenues financed by businesses, to increase to 0.31 from 0.25 . Thus, even if the local government raised the same total amount of property tax revenue, businesses pay more in taxes.

\section{The Policy Change}

In 2001, Minnesota altered the definition of local property tax base and as a result changed homestead tax shares and homestead ratios within cities. In that same year, Minnesota changed its school finance system by sharply increasing state aid to school districts and also made changes to the distribution of state aid to cities. These two additional policy changes are controlled for in the empirics. Also controlled for in the empirics is the imposition of a new property tax levy limit on some cities. Changing the definition of the property tax base affects public service demand via residents' tax prices; the changes in state aid to cities and schools affect public service demand via an income effect; and the levy limit may constrain the behavior of cities in response to these changes in tax price and income.

First, I explain the policy change that altered the definition of property tax base and changed city residents' tax prices.

In Minnesota, determining a city's total tax base requires two distinct steps. The first step in determining a city's property tax base is the annual determination, by local assessors, of the estimated market value of individual properties. The administration of this first step was not changed in 2001. The second step in determining the local property tax base is the assignment of each property to a class such as Residential Homestead, Commercial-Industrial, or Agricultural Homestead and the multiplication of each property's estimated market value by a class rate, $z_{c} \in[0,1]$, where subscript $c$ denotes the property class. Class rates determine the percentage of a property's estimated market value that is taxable, are set each year by the state legislature, and do not vary across communities. In 2001, the state legislature changed the second step by changing class rates.

Table 1 displays some of the property classes and the class rates that the state legislature altered in assessment year 2001. These class rate changes first affect property tax bills paid in 2002

\footnotetext{
${ }^{9}$ Homestead tax share derivation: $(10 \times \$ 100,000+10 \times \$ 50,000) /(10 \times \$ 100,000+10 \times \$ 50,000+\$ 500,000)=$ $0.75)$

${ }^{10}$ Total tax base $(B)$ equals $\$ 2,000,000$. Rich voter tax price: $\$ 100,000 /(B / 20)=1$. Poor voter tax price: $\$ 50,000 /(B / 20)=0.5$.
} 
(i.e., bills based on 2001 assessed values).11 Class rates are marginal rates that can increase as property value increases. Consider a commercial-industrial property with an estimated market value of $\$ 200,000$ in the year 2000. Table 1 demonstrates that the class rate on the first $\$ 150,000$ of estimated market value is $2.4 \%$ and the class rate on estimated market value over $\$ 150,000$ is $3.4 \%$, producing a taxable value of $\$ 5,300$. As another example, consider the year 2000 taxable value of a residential homestead property with an estimated market value of $\$ 70,000$. The class rate on this property was 0.01 , producing a taxable value of $\$ 700$. The product of taxable value and the property tax rate determines tax liability.

The largest and most important - in terms of tax base - class rate changes were those for commercial-industrial property and high-valued homes. Commercial-industrial property makes up by far the largest share (60\%) of cities' non-homestead property. The commercial-industrial class rate on the first $\$ 150,000$ of estimated market value fell from $2.40 \%$ to $1.50 \%$ and the class rate on estimated market value above $\$ 150,000$ decreased from $3.40 \%$ to $2 \%$. Changes in residential homestead class rates were also large and had the potential to affect the tax prices of many homeowners. The class rate on homes with estimated market values between $\$ 150,000$ and $\$ 500,000$ fell from $1.65 \%$ to $1 \%$ and the class rate on value above $\$ 500,000$ fell from $1.65 \%$ to $1.25 \%$.

All else equal, the class rate changes increased cities' homestead tax shares, decreased the taxable value of many properties, increased the homestead ratios of lower-valued homes, and reduced cities' total tax bases. If tax rates were fixed over time, the entire effects of the policy change on individual taxpayers could be described by the class-rate induced reduction in the taxable value of the taxpayer's property. And, if tax rates were fixed over time the effect on a city's total revenue is described accurately by the class-rate induced reduction in its total tax base. Tax rates, however, are not fixed over time and city governments are free to respond to the policy innovation by changing their property tax levies and tax rates.

By not responding to these changes in tax price and total tax base, cities would have produced large changes in their total property tax revenues and residents' property tax bills. If cities had maintained their previous level of property tax revenues, the median increase in a homeowner's city property tax bill would have been $12 \%$. If cities had maintained their previous property tax rates the median decrease in cities' property tax revenue would have been $23 \%$. This may explain why after the reforms nearly every city changed its property tax levy and tax rate. Only 3 of the 439 cities in the sample changed their tax rates by less than 1\% (absolute value) and only seven cities changed their property tax levies by less than $1 \%$ (absolute value).12

In 2001, Minnesota also consolidated its various lump sum aid programs into one program,

\footnotetext{
${ }^{11}$ When referring to a year, I will refer to the assessment year rather than the taxes payable year.

${ }^{12}$ Even in non-reform years it is rare for tax rates to remain constant from one year to the next. In any given year, more than $90 \%$ of cities in this sample change their tax rates by more than $1 \%$ (absolute value).
} 
producing (from 2000 to 2001) a net loss in state aid to all cities of $\$ 60.3$ million. Despite the decrease in the state's total aid disbursement, because the aid formula was not identical across the old non-consolidated aid programs, the new consolidated formula caused some cities to experience an increase in total aid. The median percentage change in total aid received by cities from 2000 to 2001 was a $6.26 \%$ increase. The inter-quartile range of aid changes, however, is approximately 30 percentage points with the $25^{\text {th }}$ percentile aid change at $-11 \%$ and the $75^{\text {th }}$ percentile aid change at $22 \%$. City residents and policy makers were aware of their city's lump sum aid amount before making spending and revenues decisions for the following year. Both before and after the consolidation, the vast majority of aid, $80 \%$, was distributed according to a base amount which has remained fixed since 1993. The remaining lump sum aid was distributed according to a formula. Each city's formula aid is equal to a percentage of the difference between its "need" and "ability to pay". Ability to pay is the city's total tax base and need is based on four factors: population, population decrease, percent of its housing built before 1940, and percent of its tax base that is classified as commercial or industrial. As a result of this formula, some additional funds were directed to cities experiencing decreases in the commercial-industrial share of their tax base as a result of the class rate changes. Because the change in aid has no effect on residents' tax prices, any implications for local fiscal behavior operate via an income effect ${ }^{13}$ Lump sum aid to cities and taxpayers from a set of other existing programs did not change dramatically and any small year-to-year changes are controlled for in the empirics. ${ }^{14}$

The effects of the school finance reform on city governments' fiscal decisions also operate exclusively via an income effect. The school finance reform did not directly affect cities' finances or homeowners' city property tax bills but did reduce residents' school district property tax bills. As a result of increased state aid to school districts accompanied by new strict limits on school district property tax rates, from 2000 to 2001 homeowners' school district property taxes fell by an average of over $50 \% .15$

The lone remaining policy change was the imposition, for taxes payable in 2002, of property tax levy limits on cities with population over 2,500 . These limits, however, were not particularly binding and thus there is no worry that we are viewing the behavior of strictly constrained local governments. These same levy limits were in effect from 1997-1999, but were not in effect in

\footnotetext{
${ }^{13}$ Bradford and Oates (1971) demonstrate an income-aid equivalence in a median voter model. See Hines and Thaler (1995) for discussion of empirical violations of this equivalence.

${ }^{14}$ There were small changes to the formula for homestead property tax credits and the amount of funds distributed via local revenue sharing. The state government also continued a sales tax rebate program that provided sales tax rebates in 1999, 2000, and 2001.

${ }^{15}$ A new uniform statewide property tax rate on non-homestead property was introduced to help finance the new state aid to school districts. Revenues from this state-wide tax go into the state government's general fund. This statewide tax does not have a price effect or an income effect on residents' demands because it does not affect their tax prices or their incomes (separate from its relationship to the reduction in school district taxes).
} 
2000, the year prior to the class rate reforms. The levy limits placed a ceiling (between $1 \%$ and $3 \%$ ) on the percentage increase in the sum of general purpose property tax revenues and state lump sum aid. The fact that general purpose property taxes revenues represent only a portion (on average $80 \%$ ) of cities' total property tax levy makes the levy limit non-binding in that the total property tax levy is not subject to the limit. Local governments can exceed the levy limit by levying non-general purpose property taxes (every city does this - even in non-limit years - and it does not require a referendum) or by passing a referendum to exceed the levy limit via the general purpose levy. The non-general purpose levies must specify their purpose (debt repayment, library improvement, etc.). Thus, it is common for the sum of cities' total property tax revenues and state lump sum aid to increase by more than allowed by the levy limit.

\section{Estimation Strategy}

This section begins by discussing the standard reduced form model used for estimating tax price and income elasticities. The endogeneity of tax price levels and tax price changes produces biased cross-sectional and fixed effects estimates of tax price elasticity. Using the 2001 class rate changes as source of exogenous variation in voters' tax price, however, allows for the identification of the tax price elasticity. Instrumenting for actual changes in voters' tax price with the tax price changes implied by the class rate change produces unbiased tax price elasticity estimates.

\subsection{Bias inherent in cross-sectional and fixed effects estimation}

Employing the constant elasticity and median voter framework common in the literature, a reduced form model using cross-sectional data to estimate the tax price elasticity of city $j$ 's per-resident property tax revenue $\left(r_{j}\right)$ looks like

$$
\ln \left(r_{j}\right)=\alpha+b_{1} \cdot \ln \left(\pi_{m j}\right)+b_{2} \cdot \ln \left(\tilde{Y}_{m j}\right)+b_{3} \cdot \ln \left(P o p_{j}\right)+\theta_{j}+u_{j}
$$

where $\alpha$ is the intercept, $u_{j}$ is the error term, and voter $m$ is the decisive voter in city $j$. This same equation, with per-resident expenditures as the dependent variable, is used to estimate expenditure elasticities. The parameters $b_{1}$ and $b_{2}$ are the price and income elasticities of revenues. A voter's total income equals her disposable income plus her share of the city's lump sum aid. Let a voter's disposable income be $y_{i}$ and the per-resident amount of lump sum aid received from higher level governments be $a_{j}$. Voter $m$ 's total income equals

$$
\tilde{Y}_{m j}=\left(y_{m}+a_{j} \cdot H R_{m j} \cdot H S_{j}\right)
$$


Thus, the homestead ratio and the homestead tax share also affect a voter's total income. $P o p_{j}$ is a city's population and controls for any economies of scale. The parameter $\theta_{j}$ represents timeinvariant city-specific unobservables such as preferences for public services, some aspects of voters' income or ability to pay, and characteristics affecting the costs of public service provision.

The cross-section estimate of the tax price elasticity is biased because of omitted variables and simultaneity. Simultaneity arises because, for example, higher property tax revenues may be positively correlated with high homestead tax shares because high-quality public services increase the value of residential property relative to commercial property and produce a high homestead tax share. This simultaneity biases estimates of the tax price elasticity towards zero because cities with higher spending and revenue also have higher homestead tax share. Unobserved differences in the marginal costs of service provision may also bias tax price elasticity estimates towards zero. Residents in cities with more commercial-industrial property have a lower homestead tax share and thus a lower tax price, but they may also face higher costs of providing public infrastructure. Further, estimating this model requires knowing the tax price and income of the decisive voter. Even when the median voter model is a suitable approximation of local public service outcomes, it will be difficult to accurately identify a decisive voter's tax price. At best, the difficulty in identifying the median tax price and income creates attenuation bias from measurement error. ${ }^{16}$

Using fixed effects eliminates much of the omitted variable bias inherent in cross-sectional estimates because it controls for characteristics of cities that are time-invariant over short periods - such as median voters' preferences, wealth, and income, as well as cities' marginal costs of service provision - that are difficult to observe.

With two years of data, fixed effects is equivalent to first differences. After substituting for tax price and total income using equations 2 and 4 , allowing each component of tax price its own coefficient ${ }^{17}$, and taking first differences, $\Delta x_{t} \equiv x_{t}-x_{(t-1)}$, equation 3 becomes

$$
\begin{aligned}
\Delta \ln \left(r_{j t}\right) & =\gamma_{t}+\phi_{1} \cdot \Delta \ln \left(c_{j t}\right)+\phi_{2} \cdot \Delta \ln \left(H R_{m j t}\right)+\phi_{3} \cdot \Delta \ln \left(H S_{j t}\right) \\
& +\phi_{4} \cdot \Delta \ln \left(1-M_{j t}\right)+\phi_{5} \cdot \Delta \ln \left(1-\tau_{m j t}\right) \\
& +\phi_{6} \cdot \Delta \ln \left(y_{m t}\right)+\phi_{7} \cdot \Delta \ln \left(\tilde{A}_{m j t}\right)+\phi_{8} \cdot \Delta \ln \left(P o p_{j t}\right)+\Delta u_{j t}
\end{aligned}
$$

The time-invariant unobservables, $\theta_{j}$, are differenced out, and $\gamma_{t}$ is a time dummy. Total income has been split into two terms, median income and adjusted aid, where adjusted aid $\left(\tilde{A}_{j t}\right)$ equals

$$
\tilde{A}_{j t}=1+\frac{a_{j t} \cdot H R_{m j t} \cdot H S_{j t}}{y_{m t}}
$$

\footnotetext{
${ }^{16}$ See, for example, Goldstein and Pauly (1981).

${ }^{17}$ The null hypothesis is that $\phi_{1}=\phi_{2}=\phi_{3}=\phi_{4}=\phi_{5}$.
} 
Using this within-city variation, however, often produces endogenous and imprecise estimates of the tax price elasticity. Estimates are imprecise because it is often the case that within-city changes in tax prices are small and thus standard errors are too large to reject a large range of values for the price elasticity. Endogeneity arises from simultaneity when changes in a city's revenue or expenditure cause, via capitalization or migration, changes in a city's homestead tax share. Again, this simultaneity will bias the tax price elasticity estimate towards zero. After differencing the error term contains only unobservables that change over time. Thus, omitted time-varying variables - trends in the value of property across and within cities affecting tax shares and revenue - create endogeneity that biases the tax price elasticity. For instance, cities with increasing population often experience an associated increase in homestead tax share. But the increase in population may also be associated with an increasing trend in tax revenues and expenditures. Failing to control for these upward trends in tax share, revenue, and expenditure will bias tax price elasticity estimates towards zero. In addition, appreciation in home values relative to commercial real estate values increases homestead tax share but also the wealth of homeowners. Since wealth increases will increase the demand for public expenditures, using homestead tax share variation caused by wealth increases will bias the tax price elasticity towards zero. Further, as with the cross-sectional estimates, accurate measures of median homestead ratio changes rely on the correct identification of the median voter's home value and the correctness of the median voter theory exactly as specified; incorrect identification of the median voter again creates measurement error.

\subsection{The policy change as an instrumental variable}

The exogenous tax price variation created by the class rate changes in Minnesota allows first difference regressions to produce precise causal estimates of the tax price elasticity of tax revenues and expenditures. Estimates are causal (i.e., unbiased) because the class rate changes produce changes in the homestead tax share and homestead ratio that are not caused by simultaneous changes in property taxes, expenditures, or public service demand. Further, the changes in the homestead tax share and homestead ratio are not correlated with changes in the marginal costs of service provision or the housing wealth of homeowners. These features make the class rates changes a source of plausibly exogenous variation in voter tax prices.

The class rate changes, especially their exact nature, were unanticipated prior to 2001 . The initial reform proposal from Governor Jesse Ventura involved reductions in the class rates of commercial-industrial property and high-valued homes. The Ventura proposal also included reductions in school district property taxes funded by a state takeover of most public school financing. Although there was agreement on school finance reform, serious disagreement existed between the 
State House and Senate on the magnitude of and desirability of class rate reductions. Proponents argued that the class rate changes were necessary to increase the uniformity of the class rates, while opponents argued that any increase in uniformity would necessarily result in enormous tax increases for some homeowners. Prior to May 25, 2001, the legislature was in "one of the worst deadlocks in recent times," with Governor Ventura forced to call a special legislative session to "forestall a wholesale shutdown of state government." On Friday, May 25, 2001, the Minnesota state legislature reached an agreement on changes to the property tax system. ${ }^{18}$

I focus first on the class rate induced variation in homestead tax share.

As stated above, usually the small magnitude of annual within-city homestead tax share changes produces large standard errors that prevent the precise estimation of the tax price elasticity. The class rate changes solve this problem by producing large changes in homestead tax shares. It is rare to observe such substantial shifts in cities' homestead tax share and thus the tax prices of residential taxpayers. Figure 1 shows the fraction of cities with relatively small annual changes - less than $10 \%$ in absolute value - in three separate variables: homestead tax share, property tax revenue, and the city property tax rate. In 1999 and 2000, over $90 \%$ of cities experience less than a $10 \%$ change in homestead tax share, but in 2001, only $40 \%$ experience these small changes. The substantial within-city tax share variation for the majority of cities in the reform year helps produce precise tax price elasticity estimates.

The policy change is responsible for nearly all of the within-city homestead tax share changes. Figure 2 shows the between-city distribution of homestead tax shares $\left(H S_{j t}\right)$ before and after the class rate changes. Both pre-reform and post-reform there is substantial across-city variation in homestead tax shares. The 2001 homestead tax share distribution — after the class rate change is a substantial rightward shift from the 2000 homestead share distribution. The lack of change in the market share distribution demonstrates that class rate changes are responsible for nearly all of the shift in the tax share distribution. To see this, note that homestead market share differs from homestead tax share only because of the class rate system and that the distribution of the homestead market share changes minimally from 2000 to 2001.

Although the policy change is responsible for most of the actual within-city variation in homestead tax share, it is not responsible for all of the variation. The homestead tax share variation implied only by the class rate changes is exogenous, but the variation not caused by the class rate changes, but by changes in the distribution of market values within a city, may be endogenous.

Because of the potential endogeneity of the actual within-city changes in homestead tax share, I use the large and unanticipated changes in the homestead tax share implied by the class rate changes as an instrumental variable. The implied change in homestead tax share, $\Delta \ln \left(H S^{*}\right)$, serves as an instrumental variable for the actual change in homestead tax share. The first stage

\footnotetext{
${ }^{18}$ Source: Minneapolis Star Tribune, May 17, 2001, page 1B and May 26, 2001, page 1A.
} 
equation:

$$
\Delta \ln \left(H S_{j, 2001}\right)=a+\beta_{1} \Delta \ln \left(H S_{j, 2001}^{*}\right)+\beta_{2} \Delta X_{j, 2001}+\epsilon_{j, t}
$$

also includes, in the vector $\Delta X_{j, 2001}$, the relevant control variables.

The implied change in homestead tax share is defined as the difference between the homestead tax share in 2001 under the new class rates but the old, 2000, property values and the actual homestead tax share in 2000.

$$
\Delta \ln \left(H S_{j}^{*}\right)=\ln \left(H S_{j, 2001}^{*}\right)-\ln \left(H S_{j, 2000}\right)
$$

where the implied homestead tax share in 2001 is defined as

$$
H S_{j, 2001}^{*}=f\left(z_{2001}, E M V_{2000}\right),
$$

as opposed to the actual homestead tax share in 2001,

$$
H S_{j, 2001}=f\left(z_{2001}, E M V_{2001}\right)
$$

where $z_{t}$ is a vector of class rates, $E M V_{t}$ is a vector of all the estimated market values in the city, and $f$ is a function mapping market values and class rates into homestead tax shares. The product of the new post-reform 2001 class rates and the old pre-reform 2000 estimated market values produces an implied taxable value for each property class. Using the 2000, rather than 2001, property values ensures that the implied change in homestead tax share contains only class-rate induced portion of total tax price variation and not endogenous changes in property values. These implied taxable values are used to calculate the ratio of implied homestead taxable value to implied total taxable value (i.e., homestead tax share). The actual homestead tax share in 2001 equals the product of the new post-reform class rates and the new post-reform 2001 estimated market values.

Substantial across-city heterogeneity in the implied homestead tax share changes allows for the estimation of unbiased tax price elasticity estimates. Much of the heterogeneity in implied homestead tax share changes is created by persistent - time-invariant - differences across cities in tax base composition. Cities with initially high actual homestead tax shares receive, on average, smaller increases in implied homestead tax share. The variation in implied tax share caused by persistent differences like the presence of commercial property is exogenous because the firstdifferences estimation controls for differences in persistent initial conditions. That is, the size of a city's homestead tax share change is not correlated with city-specific trends that could bias tax price elasticity estimates. As an example, consider two similarly sized Minnesota cities, Grand Rapids and Orono. Grand Rapids with its 29\% actual homestead tax share in 2000, did not receive a larger implied homestead tax share change than Orono, and its $84 \%$ actual homestead tax 
share in 2000, because Grand Rapids happened to spend a temporarily high amount in 2000 or because home prices were appreciating more rapidly in Grand Rapids than in Orono. Rather, Grand Rapids received the larger implied change in homestead share because the persistent determinants of its expenditure and homestead tax share are different than Orono's persistent determinants of expenditure and homestead tax shares.

If initial homestead tax share predicted exactly the change in homestead tax share, identification of the tax price elasticity comes solely from differences in initial homestead tax share. If the initial homestead tax share is correlated with time-variant unobservables - like a upward trend in expenditures - the estimates may be biased. Figure 3 displays the distribution of implied changes in homestead tax share across five quantiles of year 2000 (pre-reform) actual homestead tax share. The white line in each box represents the median implied change in homestead tax share and the ends of each box represent the 25th and 75th percentiles.19 The first quantile of initial actual homestead tax share has a median homestead tax share of $39 \%$ in 2000 and a median implied change in homestead tax share of approximately $23 \%$. The third quantile of initial actual homestead tax share has a median homestead tax share of $61 \%$ and a median implied change in homestead tax share of approximately $15 \%$. The figure illustrates that the median implied change in homestead tax share declines across the five groups, but that there is substantial overlap in the interquartile ranges. Cities with very similar initial homestead tax shares experience very different implied changes and cities with very different initial homestead tax shares experience similar implied changes.

Cities with almost identical homestead tax shares can experience different implied changes in homestead tax share because the effects of class rate changes on homestead tax share depend on not only on initial homestead tax share but also on subtle aspects of the distribution of market values within and across property classes. For example, Mankato (28\%) had a slightly lower actual homestead tax share than Grand Rapids (29\%) in 2000, yet experienced a smaller increase - $22.4 \%$ compared to $27.7 \%$ — in implied homestead tax share because of subtle differences in the distribution of market values within and across property classes. As long as these subtle differences are not correlated with city-specific trends, the orthogonality of some homestead tax share changes to the initial homestead tax share provides a source of quasi-random variation with which to estimate the tax price elasticities.

One of the advantages of the Minnesota policy change is that it produces variation in two components of tax price - $H S$ and $H R$ - that allows for the separate identification of their effects on revenues and expenditures. Necessary for separate identification is that cities with very similar

\footnotetext{
${ }^{19}$ The endpoints of the whiskers are the upper and lower adjacent values. The upper adjacent value is the largest data value that is less than or equal to the third quartile plus $1.5 \mathrm{x}$ (Inter Quartile Range) and the lower adjacent value is the smallest data value that is greater than or equal to the first quartile minus $1.5 \mathrm{x}$ IQR.
} 
changes in homestead tax share experience different changes in their median homestead ratio. Figure 4 displays the distribution of implied changes in homestead tax share across five quantiles of the implied change in the homestead ratio. If changes in the median homestead ratio perfectly predicted changes in homestead tax share the boxes would have little to no height. Instead, the boxes indicated an interquartile range of as much as 10 percentage points. Thus, there is enough uncorrelated variation in homestead tax share and median homestead ratio changes to separately identify their effects.

The implied change in a city's median homestead ratio is defined as

$$
\Delta \ln \left(H R_{m, j, 2001}\right)=\ln \left(H R_{m, j, 2001}^{*}\right)-\ln \left(H R_{m, j, 2000}\right)
$$

where the implied median homestead ratio in 2001 is a function of the estimated market value of the median voter's property in 2000, a vector of the estimated market value of each parcel of residential real estate in 2000, and the new 2001 class rates,

$$
H R_{m j, 2001}^{*}=f\left(v_{m, j, 2000}, E M V_{j, 2000}, z_{2001}\right)
$$

The actual median homestead ratio in 2000 is a function of the estimated market value of the median voter's property in 2000, a vector of the estimated market value of each parcel of residential real estate in 2000, and the old 2000 class rates.

The two components of tax price - HR and $H S$ - also affect adjusted aid $\tilde{A}_{m . j, t}$ and thus adjusted aid also has an implied change, which is a function of the implied changes of $H R$ and $H S$, as well as the level of lump sum aid and the median voter's income. Because adjusted aid $(\tilde{A})$ is a function of the product of $H R$ and $H S$, it is not perfectly predicted by either variable on its own and it can be identified separately from those two variables. The first stage equations for $H S$ and $\tilde{A}$ are defined in the same manner as the first stage for $H S$.

In years without class rate changes, all years except 2000 to 2001, the changes in the instrumental variables $-\Delta H S^{*}, \Delta H R^{*}, \Delta \tilde{A}^{*}$ - are set to zero.

One may also worry that because class rates changes also affect the level of total tax base that it will be difficult to separately identify the effect of changes in tax price on revenues from any effect of changes in level of the total tax base on revenues. There are three reasons not to worry about this issue. First, changes in the homestead tax share are not strongly correlated with changes in the total tax base and thus these effects can be separately identified. Because percentages changes in homestead tax share are approximately equal to the percentage change in the total taxable value of homesteads minus the percentage change in total tax base, if changes in $H S$ were driven entirely by total tax base changes, the correlation between the percentage change in total tax base and the percentage change in $H S$ would be close to negative one. In fact, the class rate changes produced 
a correlation between $H S$ and tax base of -0.09 . Second, including changes in the (natural $\log$ of the) total base as an independent variable does not change any results and the coefficient is zero. Third, in the median voter framework, holding tax price constant, changes in the total tax base induced by the class rate changes are nominal and have no effect on voters' demands for tax revenues or expenditure. Thus, in the median voter framework, total tax base does not belong in the regression as an independent variable.

\subsection{Estimating equations and first stage results}

In our main specifications we use only differences from 2000 to 2001, the years immediately before and after the policy change. These are the only years in which are instruments predict any change in tax price.

One problem with estimating equation 5 is that, because changes in the variables $H R,(1-\tau)$, $y$, and $\tilde{A}$ vary across a city's residents, it requires a decision on which resident's changes in $H R$, $(1-\tau), y$, and $\tilde{A}$ are most relevant to the city's decisions on revenues and expenditures. In a median voter model, the specification must include the changes in these variables for the decisive or median voter. This is a disadvantage because, if a median voter exists, he or she will be difficult to identify or approximate. If these variables are measured incorrectly they may bias the price elasticity estimate towards zero. Further, the specification of adjusted aid and median homestead ratio variables only properly control for changes in tax price and adjusted aid if the median voter model is literally true as derived.

Although the policy change creates implies homestead tax share changes that differ across cities, the implied homestead tax share changes are identical for all residents within a city $20 \mathrm{Be}$ cause all of a city's residents experience identical changes in implied homestead tax share, estimation does not require the identification of a median voter. To avoid problems associated with identifying a median voter, the following equation omits variables that require knowledge of a median voter: $H R, y$, and $(1-\tau)$.

$$
\begin{aligned}
\Delta \ln \left(r_{j t}\right) & =\gamma_{t}+\phi_{3} \cdot \Delta \ln \left(H S_{j t}\right)+\phi_{a} \cdot \Delta \ln \left(a_{j t}\right)+\phi_{8} \cdot \Delta \ln \left(\text { Pop }_{j t}\right) \\
& +\phi_{9} \cdot \Delta \ln \left(\operatorname{SchoolTax}_{j t}\right)+\phi_{10} \cdot \text { LevyLimit }_{j t}+\Delta u_{j t} .
\end{aligned}
$$

This modified version of equation 5 is the main specification for the tax price elasticity estimates. The modifications are: changes in real marginal costs and the matching grant rate are assumed to be zero $\left(\Delta c_{j t}=0\right.$ and $\left.\Delta\left(1-M_{j t}\right)=0\right), \Delta H R_{m}, \Delta y_{m}$, and $\Delta\left(1-\tau_{m}\right)$ have been omitted and are assumed uncorrelated with changes in $H S, \tilde{A}_{m}$ has been replaced with lump sum aid (which

\footnotetext{
${ }^{20}$ Taking the natural $\log$ of equation 2 and totally differentiating demonstrates that, all else equal, a percentage change in homestead tax share produces approximately the same percentage change in all residents' tax prices.
} 
does not require information on the median voter), and SchoolTax ${ }_{j t}$ and LevyLimit ${ }_{j t}$ control for the effects of additional policy changes. ${ }^{21}$ The variable $\Delta \ln \left(\operatorname{SchoolTax}_{j t}\right)$ controls for the change in average school district property taxes paid by a city's residents that was caused by the school finance reform. This coefficient should be negative because of the income effect of tax payments. The binary variable LevyLimit ${ }_{j t}$ equals one when a city is under a levy limit and zero when a city is not. This coefficient is expected to be negative, but also to be relatively small because the levy limits do not appear to be very binding. This equation is estimated via 2SLS with the implied change in $H S$ as the instrumental variable. In some specifications, equation 13 incorporates cityspecific linear trends by adding two pre-policy change differences (1998-1999 and 1999-2000) and $j$ city dummies, $\phi_{\text {city- } j}$.

I also estimate the following equation that includes some of the variables that require knowledge of the median voter,

$$
\begin{aligned}
\Delta \ln \left(r_{j t}\right) & =\gamma_{t}+\phi_{2} \cdot \Delta \ln \left(H R_{m j t}\right)+\phi_{3} \cdot \Delta \ln \left(H S_{j t}\right)+\phi_{7} \cdot \Delta \ln \left(\tilde{A}_{m j t}\right) \\
& +\phi_{8} \cdot \Delta \ln \left(\operatorname{Pop}_{j t}\right)+\phi_{9} \cdot \Delta \ln \left(\operatorname{SchoolTax}_{j t}\right)+\phi_{10} \cdot \text { LevyLimit }_{j t}+\Delta u_{j t}
\end{aligned}
$$

In this specification the implied changes in $H S, H R$, and $\tilde{A}$ all serve as instrumental variables.

The results from each of the first stage regressions are in Table 3. The first three columns present the first stage results for homestead tax share. To measure how much of the actual variation in $H S$ is explained by the implied $H S$ changes, column (1) reports the results from a univariate regression of the actual $\Delta \ln (H S)$ change on the implied $\Delta \ln \left(H S^{*}\right)$ change. The $R^{2}$ of 0.79 indicates that, from 2000 to 2001, almost 80 percent of the variation in actual tax shares is explained by the class rate changes. The coefficient on the implied $H S$ change, 0.997 , indicates that one percent increase in the implied homestead share is associated with an approximate one percent increase in the actual share. The similarity of the implied changes and the actual changes implies that, with these data and in these two years, an instrumental variables approach is almost unnecessary. Column (2) reports the results from the first stage that is used in the 2SLS estimation of equation 13. Columns (3) through (5) report the results from the first stage regression used in the 2SLS estimation of equation 14. In, column (4), the $R^{2}$ and the coefficient on $\Delta \ln \left(H R^{*}\right)$ of 1.1 again imply that implied changes in $H R$ explain well the actual $H R$ changes. In column (5), the coefficient on $\Delta \ln \left(\tilde{A}^{\star}\right)$ implies the same about implied and actual changes in adjusted aid. Because the instruments, implied changes in $H S, H R$, and $\tilde{A}$, explain so much of the actual variables, using data in the years just before and after the policy change $(2000-2001)$ produces OLS coefficients that are very similar to 2 SLS.

Thus, in order to see the bias inherent in fixed effects estimates, it is necessary, for comparison,

\footnotetext{
${ }^{21}$ Note that Figure 4 demonstrated that changes in $H S$ and $H R$ do not have a strong association.
} 
to estimate our regressions using data from years without a policy change, where much of the variation in homestead tax share is presumably endogenous. In section 5 I compare regression results that use data from 1998-1999, which is two years before the policy change, to regression results that use data from 2000-2001. The choice of the non-reform years (1998-1999) is arbitrary as OLS results from other non-policy years, before and after 2001, are similar.

\section{Data and Measurement}

The estimating sample consists of 439 cities in Minnesota with a population of greater than or equal to 500 each year from 1998 to 2003. As noted earlier, in Minnesota, cities are the most numerous type of fiscally independent local government with substantial populations. Property taxes are the main independent source of financing cities' expenditures and cities enjoy relatively broad access to their property tax base 22

Administrative data on the composition and level of the property tax base, requested property tax revenues (i.e., levies), and property tax rates for all cities in Minnesota for the years 1998-2003 are from the Minnesota Department of Revenue. ${ }^{23}$ These property tax data contain information not only on city property taxes but also other property taxes levied on city taxpayers. That is, they contain data on total county taxes, special district taxes, and school district taxes paid by taxpayers in a specific city. Data are at the taxing jurisdiction level and do not include information on individual properties within taxing jurisdictions.

When discussing property taxation, any reference to a year can sometimes be confusing. This confusion arises because the administration of the property tax creates a two-year tax cycle. For example, an individual taxpayer's property tax bill in 2002 (the taxes payable year is 2002) is based on estimated market values finalized on January 2, 2001 (the assessment year is 2001). Although the tax base is determined on Jan 2, 2001, requested property tax revenues are not finalized until December 2001. Property tax bills based on the Jan 2, 2001 assessments and the December 2001 revenue requests are due in 2002. All of the reforms discussed above occurred in assessment year 2001 and they first have direct effects on property taxes payable in 2002. When mentioning a year, this paper refers to the assessment year.

The Office of the State Auditor provided detailed information on the revenues and expenditures of all cities in Minnesota. These data include state aid amounts to cities and expenditures by expenditure type(e.g., current vs. capital, public safety, streets and highways). In specifications that include the adjusted aid variable, median household income is from the U.S. Census and is only available for 1999. In these specifications, median household income is assumed constant

\footnotetext{
${ }^{22}$ Minnesota cities have representative governments.

${ }^{23}$ Data are from the Abstract of Assessments and the Abstract of Tax Lists.
} 
over time.

Some specifications include the median homestead ratio. Measurements of the median homestead ratio, $H R$, require the median taxable value of a city's homes, which is the numerator of $H R$. Data from the Department of Revenue, however, do not include information on median taxable value. Data on median home value are available, for 1999 only, from the U.S. Census. The taxable value is calculated as the product of this median value and the appropriate class rates. The denominator of $H R$ is the average taxable value of a city's homes, which is available in the Department of Revenue data. Because, for each city, there is only one observation for median home value, all variation in the numerator of $H R$ is caused by class rate changes. In years without class rate changes - e.g., 1999 to 2000 - any changes in $H R$ are caused by changes in the average market value of homes.

Table 2 displays summary statistics for the estimating sample. When applicable, variables are adjusted for inflation using the Urban CPI for all consumers.

\section{Results}

In this section I discuss the results of using the presumably exogenous variation in homestead tax share to estimate the tax price elasticity and separately identify it from contaminating factors such as unobservable city-level heterogeneity.

\subsection{Property tax revenues}

Table 4 presents regression results where the dependent variable is the change in the natural log of cities' requested per-resident property tax revenues. I discuss the price elasticity estimates in each of the columns before turning to a discussion of the control variables.

Column (1) estimates equation 13 using data from the pre-reform years of 1998-1999, well before the reforms are proposed and implemented. There is no policy change from 1998 to 1999 so column (1) does not use the instrumental variable, nor does it control for city-specific trends. Again, because the instrument explains almost all of the variation in homestead tax share during the policy change years, comparing regression results from pre-reform years to results from reform years is the only way to see the potential bias produced by endogenous tax prices. Using these prereform years, the estimated price elasticity of revenues is -0.25 , suggesting that a one percent increase in tax price is associated with a one-quarter of a percent decrease in per-resident property tax revenues.

Column (2) uses data from the class rate reduction period of 2000-2001 to estimate an equation via 2 SLS, with homestead tax share as the sole explanatory variable and implied homestead tax 
share as the instrumental variable. Estimation produces a tax price elasticity of -1.040 that is statistically different from zero, but not statistically different from negative one. Column (3) presents results from the estimation of equation 13, which is the column (2) regression with control variables. The coefficient on homestead tax share is now -1.063 and it is statistically different from zero but not from negative one. That the coefficients in column (2) without controls and column (3) with controls are nearly identical demonstrates that the instrumental variable is orthogonal to these unobservables and is consistent with the instrumental variable being exogenous.

The estimated coefficients in columns (2) and (3) do not rely on the identification of a median voter. The estimated tax price elasticities in these columns suggest that a one percent increase in tax price is associated with an approximately one percent decline in per-resident property tax revenues. A coefficient of one implies that as homestead tax share increases, property tax revenues are adjusted so that the total property taxes paid by homeowners remains unchanged. These results reject the null hypothesis that the price elasticity of property tax revenue is as small as -0.47 . That the non-IV estimate reported in column (1) is not even in this confidence interval is strong evidence of substantial downward bias in the non-IV first differences regression.

A mechanical response to the class rate changes, a response that leaves real revenues constant, results in a price elasticity of zero. This null hypothesis is rejected. One could argue that cities might hold tax rates constant rather than hold revenues constant. Constructing a counterfactual constant tax rate response for each city is straightforward. This counterfactual response (i.e., revenue level) is the old pre-reform 2000 tax rate multiplied by the new post-reform 2001 tax base. Regressing this counterfactual response against the right hand side in column (2) produces an estimated price elasticity of -0.42 . Thus, the hypothesis that these results represent a mechanical response from constant tax rates is rejected.

Column (4) displays the results of estimating equation 14 . These estimates require the identification of a median voter and may be subject to measurement error and attenuation bias. The coefficient on homestead tax share is now -0.794 and is still statistically different from zero and not statistically different from negative one. As the basic theory and tax price equation suggest, it is not possible to reject the null hypothesis that the coefficients on homestead tax share and median homestead ratio $(-0.830)$ are equal. If the true tax price elasticity is negative one, these results suggest attenuation bias from measurement error. It's also possible, however, that, by not including $H R$ and $\tilde{A}$, the regressions in columns (2) and (3) overestimate the elasticity (absolute value). These data do not allow for any differentiation between these two stories. The bottom line, however, is that all of the price elasticity point estimates are close to negative one and far from zero.

Column (5) returns to estimating the equation that does not require identification of the median voter, but now city-specific linear time trends are included as an explanatory variable. The coeffi- 
cient on homestead tax share, -1.023 is again statistically different from zero but not statistically different from negative one. The similarity of this coefficient to all of the preceding coefficients suggests that the instrumental variable is not correlated with unobserved linear trends and that the results in columns (2) through (4) are unbiased.

Column (6) estimates a fixed effects (FE) model rather than a first difference (FD) model and controls for city-specific linear trends. With more than two time periods FE estimation can produce different parameter estimates and can offer efficiency gains over FD if the error terms in equation 13 are serially uncorrelated ${ }^{24}$ Large differences in the FE vs. FD estimates may also suggest violations of assumptions regarding the exogeneity of independent variables. Column (6) produces a FE estimate of the price elasticity, -0.995 that is close to the FD estimate in column (5), with only a small reduction in the standard error. Results in columns (5) and (6) allow for the rejection of null hypotheses that the tax price elasticity of property tax revenue is -0.5 . Thus, even after controlling for linear city-specific trends, that the non-IV estimate reported in column (1) is not even in this confidence interval is again strong evidence of substantial downward bias in the non-IV first differences regression.

The point estimates for the control variables are consistent across the columns. I focus on interpreting the point estimates in column (5), which are the results from the regression that controls for city-specific linear trends.

The coefficient on changes in the natural log of total aid suggests that a one percent increase in total per-resident lump sum aid is associated with an almost three percent decline in property tax revenues. This suggests that local governments use aid to provide some property tax relief. For a city with mean year 2000 characteristics, this implies that a one dollar increase in total perresident lump sum aid is associated with a 50 cent reduction in per-resident property taxes. This appears inconsistent with the flypaper effect because the marginal propensity to consume out of a lump sum aid increase is at least as large as usual estimates of the marginal propensity to fund public expenditures out of additional income ${ }^{25}$ Instead of lump sum total aid, the regression in column (4) uses adjusted aid as a control variable. For a city with average characteristics - perresident aid of $\$ 1,160$, median income of $\$ 30,000$, and homestead tax share of $60 \%$ - a one percent increase in adjusted aid corresponds to a $2.32 \%$ increase in lump sum aid ${ }^{26}$ Using this equivalence, the coefficient on adjusted aid, -2.340 , suggests that one percent increase in lump sum aid is associated with an approximately one percent reduction in per-resident property tax

\footnotetext{
${ }^{24}$ See Wooldridge (2002), section 10.7, page 284 for a discussion of fixed effects vs. first-differencing.

${ }^{25}$ The flypaper effect (e.g., Hines and Thaler 1995) is explicitly defined as a difference in the marginal propensity to spend out of grants and income, as opposed to differences in elasticities. The construction of the adjusted aid variable is meant to make aid and income elasticities comparable. See Inman (1979).

${ }^{26}$ After totally differentiating and using some algebra: $\frac{d \tilde{A}}{\tilde{A}}=\left(\frac{d a}{a}\right)\left[\frac{a \cdot H S}{\tilde{A} \cdot Y}\right]$. With $Y=30,000, H S=0.6$, $a=1,160, \tilde{A}=1$, the equation implies $\frac{d a}{a}=\frac{d \tilde{A}}{\tilde{A}}(0.0232)$.
} 
revenues. Thus, for this average city and consistent with the column (5) results, lump sum aid is used to finance reductions in property taxes.

The coefficient on school tax is not significantly different from zero in any of the columns, suggesting that the reduction in school district tax payments had little to no effect on cities' property taxes. The coefficient on the change in the natural log of population shows the most variation across columns. In column (5) the point estimate, -0.918 , implies that a one percent increase in population is associated with an approximately one percent decline in per-resident property tax revenues. This is consistent with the hypothesis that cities keep the level of property tax revenues fixed as population increases by one percent ${ }^{27}$ This hypothesis cannot be rejected in any of the results in columns (2) through (6).

As expected, the coefficient on the levy limit dummy is negative and not statistically different from zero in nearly all specifications. Only in column (5) is the coefficient, -0.045 , different from zero. The point estimate in column (5) implies that cities subject to the levy limit had per-resident property tax revenues that were lower by 4.5 percent. At the mean level of per-resident property tax revenue in 2000 , this effect is approximately $\$ 8.90$. The coefficients in other columns all imply a much smaller effect.28

\subsection{Expenditures}

Because cities have more than one source of revenue, the negative price elasticity of property tax revenues does not necessarily imply a negative expenditure elasticity. Table 5 presents results from first difference regressions where the dependent variable is either the change in the natural $\log$ of per-resident total expenditures, per-resident current expenditures, or per-resident capital expenditures. These regressions all estimate equation 13, which does not require identification of the median voter. All regressions control for city-specific linear time trends. For comparison, column (1) reports again the property tax revenue results from Table 4, column (5). If all property tax reductions were transformed directly into expenditure decreases, other revenue remained constant, and current revenues equaled current expenditures, the price elasticity of expenditure should be about a third the size of the price elasticity of property tax revenue.

In column (2), the coefficient on homestead tax share, -1.163 , indicates that a one percent increase in $H S$ is associated with a more than one percent decline in total expenditures. The point estimate is large, but the standard error is also large (0.369), so that the null hypothesis of an elasticity of -0.40 cannot be rejected. That 0.40 is not that much larger than one-third of the tax

\footnotetext{
${ }^{27}$ To see this, note the dependent variable $\Delta \ln \left(r_{j t}\right)=\Delta\left(\ln \left(R_{j t}\right)-\ln \left(\operatorname{Pop}_{j t}\right)\right)$. With the level of revenue $(R)$ constant, the mechanical relationship between population changes and $\Delta \ln \left(r_{j t}\right)$ produces a coefficient of negative one.

${ }^{28}$ I also estimated regressions that include, in additional to the levy limit dummy itself, an interaction between the change in $H S$ and the levy limit dummy. The coefficient on the interaction term is zero.
} 
price elasticity of property tax revenue suggests that the hypothesis that most of the decrease in property tax revenues corresponds to an identical expenditure decrease cannot be rejected.29

Results from additional regressions are consistent with the change in expenditures being concentrated exclusively in the capital expenditure category. In column (3) the coefficient on homestead tax share is not statistically different from zero and implies that changes in tax price have a negligible association with current expenditures. This small coefficient is consistent with results from Rockoff (2010) and other previous estimates. The coefficient on capital expenditures, however, is large (-2.386) and statistically different from zero at the $10 \%$ level in a two-sided test. The standard error, however, is quiet large and thus there is not enough power to reject the null hypothesis of an elasticity near zero. The large standard errors and the corresponding wide confidence intervals for the capital expenditure and total expenditure estimates suggests that the large point estimates of expenditure elasticities should be interpreted with caution.

Still, the results imply that local governments respond to tax price increases by reducing capital rather than current expenditures. The small current expenditure elasticities may reflect relatively high short run political and public service costs of decreasing current expenditures. Reductions in wages may be difficult, layoffs unpopular, and service reductions unwanted. Reductions in capital expenditures may be easier to achieve. A city could delay the repair of certain streets or decide not to purchase as many new police cars and fire engines; these decisions have less immediate and perhaps even fewer long run consequences than laying off municipal employees and cutting services 30

\subsection{Robustness checks}

Table 6 presents the results from several robustness checks. All regressions estimate equation 13 .

Cities expecting a large increase in homestead tax share have an incentive to increase property taxes before the reform when property tax revenues are relatively inexpensive and then lower revenues after the voter tax share has increased. If an anticipatory increase in revenues occurs, the

\footnotetext{
${ }^{29}$ That the coefficient on expenditure could be larger than one-third the size of the tax price elasticity of property tax revenue is not inconsistent with theory or facts. To see this, note that it is not the case that annual city revenues equal annual city expenditures. Deviations between revenues and expenditures occur because cities carry large fund balances. Understanding cities' motivations to increase or decrease their fund balances requires a multi-period model of city finances that is beyond the scope of this paper. Yet, if a city reduced its property tax revenue while other revenues remain constant, a decision to increase its fund balance, could produce an expenditure elasticity approximately equal to the property tax revenue elasticity. In fact, $25 \%$ of cities increased their fund balances by more than $18 \%$ from 2000 to 2001.

${ }^{30}$ These results represent the short run response of expenditures in Minnesota cities to relatively large changes in voters' real costs of public revenues and expenditures. Examining long differences from 2000-2002, 1999-2002, and 1998-2002 (allowing an addition year for a government response) produces similar results to the differences from 2000 to 2001, 1999 to 2001, and 1998 to 2001. Examining long differences from 1999 to 2003, however, produces large standard errors that do not allow for any conclusive statements. I cannot reject, however, the hypothesis that by 2003 local governments may have, unlike in the short run, restored capital expenditures and cut current expenditures.
} 
regressions would overestimate the response of cities to changes in tax price.

Cities officially set property tax revenue and expenditure levels for the 2000 assessment year in December 2000, while the class rate changes were not determined until May 2001. The hypothesis that cities expecting larger increases in homestead tax share increased property tax revenues before the reform is investigated by estimating equation 13 with the dependent variable as the change in tax revenue from 1998 - 1999, two years before the reform, but the same explanatory variables measuring changes from 2000 to 2001.

Column (1) of Table 6 displays these results. The coefficient on the eventual increase in homestead tax share is 0.006 with a standard error of 0.099. A null hypothesis that cities did not change property revenues in anticipation of class rate changes cannot be rejected. Columns (2) and (3) display the results for the dependent variables current expenditure and capital expenditures. Again, the coefficients are not statistically different from zero. Another way to examine any effect of anticipation on results is to use longer differences where the first year of the difference is well before the policy change announcement. Columns (4) and (5) examine longer differences, from 1998 to 2001, in the response of property tax revenues and capital expenditure. Because the reform is unlikely to be anticipated in 1998, that the coefficients on $H S$ in these columns are similar to the coefficients from the main specification suggests that anticipation is not causing any of the previous regressions to overestimate the response to price.

Column (6) presents results from estimating equation 13 by weighting each observation by the city's population. These results confirm that the main results are not driven by small cities because the estimates in column (6) result from giving more weight to observations from large cities, and the tax price elasticity of property tax revenue is estimated as -1.205 , larger than the unweighted estimates.

It's possible that in cities with more commercial-industrial property that the owners of these properties have political influence even though many of them, being non-residents, cannot vote in local referenda. To examine the possibility that the political influence of commericial-industrial property owners makes tax price elasticities lower in cities with more commercial-industrial property, I split the sample and estimated equation 13 separately on cities with high commercialindustrial shares and low commercial-industrial shares. I also split the sample based on the level of commercial-industrial property rather than the share. Although not reported here, the tax price elasticities do not differ between the two groups of cities and thus the results are consistent with the previous estimates. 


\section{Conclusion}

Differences in tax prices caused by explicit government policies and differences in tax base composition are economically powerful; a one percent increase in residents' tax prices is associated with a $1 \%$ decrease in property tax revenues and similarly large decreases in expenditures. The evidence suggests that capital expenditures are sensitive to tax prices while current expenditures are not. Although using only data from Minnesota may limit the general applicability of these results, finding reliably exogenous variation in tax prices necessitates examining data for only the limited geography experiencing the policy innovation.

A tax price elasticity of property tax revenue of negative one suggests that homestead exemptions do not produce reductions in average residential property tax payments. Popular property tax relief programs appear to produce outcomes with no to little property tax relief for many homeowners, increases in tax payments for commercial-industrial property owners, and higher local government expenditure. Further, elimination or reductions of these relief programs is likely not to result in property tax increases for homeowners, but rather declines in commercial-industrial tax payments and public expenditures. A similar result is found in the flypaper effect literature, where lump sum aid does not provide tax relief.

Finally, although this paper identifies a large tax price elasticity, it does not and cannot identify whether it is the will of the voters or the will of a Leviathan-like bureaucracy that produces the observed outcomes. The large observed tax price elasticity is consistent with a leviathan model of local government in which tax relief is captured by the government in the form of higher revenues rather than by taxpayers in the form of lower tax payments. Evidence from Moomau and Morton (1992) suggests that voters understand the operation of homestead exemptions and that voters appear to believe that exemptions offer property tax reductions and/or increases in public service quality. Thus, the results are also consistent with voters' using the reduced tax prices to increase public service quality via higher expenditures but identical tax payments. Identifying the mechanism behind these results helps to answer whether or not homestead exemptions represent a transfer from commercial-industrial taxpayers to homeowners (in the form of higher quality public services) or rather from commercial-industrial taxpayers to government officials (in the form of higher expenditures with no link to service quality). 


\section{References}

Anderson, Nathan B., 2006, Beggar thy neighbor? property taxation of vacation homes, National Tax Journal 59, 757-780.

Baer, David, 1998, Awareness and popularity of property tax relief programs, Assessment Journal 5, 47-65.

— , 2003, State programs and practives for reducing residential property taxes, AARP research paper.

Bergstrom, Theodore C., and Robert P. Goodman, 1973, Private demands for public goods, The American Economic Review 63, 280-296.

Bogart, William T., and David F. Bradford, 1990, Incidence and allocation effects of the property tax and a proposal for reform, Research in Urban Economics 8, 59-82.

Bradford, D.F., R.A. Malt, and W.E. Oates, 1969, The rising cost of local public services: Some evidence and reflections, National Tax Journal 22, 185-202.

Bradford, David F., and Wallace E. Oates, 1971, An analysis of revenue sharing in a new approach to collective fiscal decisions, The Quarterly Journal of Economics 85, 416-439.

Case, Karl E., and Christopher J. Mayer, 1996, Housing price dynamics within a metropolitan area, Regional Science and Urban Economics 26, 387-407.

Case, Karl E., and Robert J. Shiller, 1989, The efficiency of the market for single-family homes, The American Economic Review 79, 125-137.

Crane, Randall, 1990, Price specification and the demand for public goods, Journal of Public Economics 43, 93-106.

Feldstein, Martin S., 1975, Wealth neutrality and local choice in public education, The American Economic Review 65, 75-89.

— , and Gilbert E. Metcalf, 1987, The effect of federal tax deductibility on state and local taxes and spending, The Journal of Political Economy 95, 710-736.

Goldstein, G.S., and M.V. Pauly, 1981, Tiebout bias on the demand for local public goods, Journal of Public Economics 16, 131-144.

Guerrieri, Veronica, Daniel Hartley, and Erik Hurst, 2010, Endogenous gentrification and housing price dynamics, NBER Working Paper Series No. 16237. 
Hines, James R., and Richard H. Thaler, 1995, The flypaper effect, Journal of Economic Perspectives 9, 217-226.

Holtz-Eakin, Douglas, and Harvey Rosen, 1990, Federal deductibility and local property tax rates, Journal of Urban Economics 27, 269-285.

Inman, Robert P., 1979, The fiscal performance of local governments: An interpretative review, in Peter Mieszkowski, and Mahlon Straszheim, ed.: Current Issues in Urban Economics . pp. 270-321 (Johns Hopkins University Press, Baltimore).

, 1989, The local decision to tax: Evidence from large u.s. cities, Regional Science and Urban Economics 19, 455-491.

Ladd, Helen F., 1975, Local education expenditures, fiscal capacity, and the composition of the property tax base, National Tax Journal 28, 145-158.

McMillen, Daniel P., 2003, Neighborhood house price indexes in chicago: A fourier repeat sales approach, Journal of Economic Geography 3, 57-73.

Moomau, Pamela H., and Rebecca B. Morton, 1992, Revealed preferences for property taxes: An empirical study of perceived tax incidence, The Review of Economics and Statistics 74, 176179.

Rockoff, Jonah E., 2010, Local response to fiscal incentives in heterogeneous communities, Journal of Urban Economics 68, 138-147.

Ross, Stephen, and John Yinger, 1999, Sorting and voting: A review of the literature on urban public finance, in Handbook of Regional and Urban Economicsvol. 3 . chap. 47, pp. 2003-2042 (Elsevier Science).

Rubinfeld, Daniel L., 1987, The economics of the local public sector, in Alan J. Auerbach, and Martin Feldstein, ed.: Handbook of Public Economicsvol. 28 . chap. 11, pp. 571-645 (Elsevier Science).

Wildasin, David E., 1989, Demand estimation for public goods: Distortionary taxation and other sources of bias, Regional Science and Urban Economics 19, 353-379.

Wooldridge, Jeffrey M., 2002, Econometric Analysis of Cross Section and Panel Data (MIT Press: Cambridge, Massachusetts). 
Table 1:

Minnesota Class Rate Changes

(share of market value that is taxable)

\begin{tabular}{l|rrrr} 
& \multicolumn{4}{|c}{ Assessment Year } \\
\cline { 4 - 5 } Class of Property & 1999 & 2000 & 2001 & 2002 \\
\hline Commercial-Industrial Land and Buildings & & & & \\
$\quad$ to $\$ 150 \mathrm{~K}$ & $2.40 \%$ & $2.40 \%$ & $1.50 \%$ & $1.50 \%$ \\
$\quad$ Over $\$ 150 \mathrm{~K}$ & $3.40 \%$ & $3.40 \%$ & $2.00 \%$ & $2.00 \%$ \\
Residential Homestead* & & & & \\
$\quad$ to $\$ 76 \mathrm{~K}$ & $1.00 \%$ & $1.00 \%$ & $1.00 \%$ & $1.00 \%$ \\
$\quad \$ 76 \mathrm{~K}$ to $\$ 500 \mathrm{~K}$ & $1.65 \%$ & $1.65 \%$ & $1.00 \%$ & $1.00 \%$ \\
$\quad$ Over $\$ 500 \mathrm{~K}$ & $1.65 \%$ & $1.65 \%$ & $1.25 \%$ & $1.25 \%$ \\
Apartments & & & & \\
$\quad$ all values & $2.40 \%$ & $2.40 \%$ & $1.80 \%$ & $1.50 \%$ \\
Non-Commercial Seasonal Recreational & & & & \\
to $\$ 76 \mathrm{~K}$ & $1.20 \%$ & $1.00 \%$ & $1.00 \%$ & $1.00 \%$ \\
$\quad \$ 76 \mathrm{~K}$ to $\$ 500 \mathrm{~K}$ & $1.65 \%$ & $1.65 \%$ & $1.00 \%$ & $1.00 \%$ \\
$\quad$ Over $\$ 500 \mathrm{~K}$ & $1.65 \%$ & $1.65 \%$ & $1.25 \%$ & $1.25 \%$ \\
\hline \hline
\end{tabular}

Source: Minnesota Department of Revenue

* indicates that these properties are considered homestead properties.

Entries represent the class rates for a subset of all property classes for assessment years 1999 through 2002. Class rates determine the percentage of a property's estimated market value that is taxable. The class rate applies only to that portion of the property's market value that is within the stated limit. For example, if a commercial property had a market value of $\$ 200,000$ in 2000 , its taxable value would be $T V=.024 \cdot 150,000+.034 \cdot 50,000$. The product of a property's class rate and market value is its taxable value. Property tax payments equal the product of a property's taxable value and the local property tax rate. The Minnesota state legislature sets class rates each year. The class rate change occurred after market values, for tax purposes, were fixed for 2001. 
Table 2:

\section{Minnesota Cities: Sample Summary Statistics}

(Standard Deviations in Parentheses)

\begin{tabular}{|c|c|c|c|c|}
\hline \multirow[b]{2}{*}{ Variable } & \multicolumn{2}{|c|}{ Averages } & \multicolumn{2}{|c|}{$\%$ Changes (2000-2001) } \\
\hline & 2000 & 2001 & Mean & Median \\
\hline Homestead Tax Share & $\begin{array}{c}60 \\
(16)\end{array}$ & $\begin{array}{c}66 \\
(15)\end{array}$ & $\begin{array}{l}12.45 \\
(8.82)\end{array}$ & 11.75 \\
\hline Commercial-Industrial Tax Share & $\begin{array}{c}31 \\
(17)\end{array}$ & $\begin{array}{c}25 \\
(14)\end{array}$ & $\begin{array}{l}-21.67 \\
(9.25)\end{array}$ & -22.93 \\
\hline Median Homestead Tax Ratio & $\begin{array}{l}1.05 \\
(.12)\end{array}$ & $\begin{array}{l}1.07 \\
(.11)\end{array}$ & $\begin{array}{c}2.49 \\
(3.62)\end{array}$ & 2.03 \\
\hline Total Aid & $\begin{array}{c}1,160 \\
(1,873)\end{array}$ & $\begin{array}{c}868 \\
(1,195)\end{array}$ & $\begin{array}{c}3.27 \\
(77.16)\end{array}$ & -0.34 \\
\hline Adjusted Aid & $\begin{array}{c}1 \\
(0)\end{array}$ & $\begin{array}{c}1 \\
(0)\end{array}$ & $\begin{array}{l}-0.26 \\
(.97)\end{array}$ & 0.05 \\
\hline School District Taxes & $\begin{array}{c}315 \\
(329)\end{array}$ & $\begin{array}{c}135 \\
(131)\end{array}$ & $\begin{array}{l}-55.97 \\
(18.91)\end{array}$ & -57.12 \\
\hline Population & $\begin{array}{c}8,656 \\
(25,830)\end{array}$ & $\begin{array}{c}8,792 \\
(25,910)\end{array}$ & $\begin{array}{c}1.65 \\
(7.37)\end{array}$ & 0.62 \\
\hline Property Tax Levy & $\begin{array}{c}198 \\
(120)\end{array}$ & $\begin{array}{c}223 \\
(119)\end{array}$ & $\begin{array}{c}14.94 \\
(26.58)\end{array}$ & 11.06 \\
\hline Total Expenditures & $\begin{array}{l}1,016 \\
(534)\end{array}$ & $\begin{array}{l}1,050 \\
(533)\end{array}$ & $\begin{array}{c}11.6 \\
(52.93)\end{array}$ & 3.59 \\
\hline Current Expenditures & $\begin{array}{c}505 \\
(184)\end{array}$ & $\begin{array}{c}518 \\
(200)\end{array}$ & $\begin{array}{c}3.46 \\
(18.74)\end{array}$ & 1.19 \\
\hline Capital Expenditures & $\begin{array}{c}341 \\
(402)\end{array}$ & $\begin{array}{c}339 \\
(390)\end{array}$ & $\begin{array}{c}111.83 \\
(644.74)\end{array}$ & -1.42 \\
\hline Observations & 439 & 439 & 439 & 439 \\
\hline
\end{tabular}

Notes: Sample is restricted to cities in Minnesota with a population $\geq 500$ in all years 1994-2003. All level variables reflect per-resident averages across observations (cities) in the sample. Variables indicating percentages of total tax base (i.e., homestead tax share) express the amount of tax base that is homestead property per $\$ 100$ of total tax base. Where appropriate, variables are in 2000 U.S. dollars. All aid is lump sum and is from the state, county, or federal government. The last two columns reflect the average and median percentage changes across observations for each variable. The year is the assessment year with all expenditures occurring in the year following the assessment year. 
Table 3:

First Stage Regressions

(Standard Errors in Parentheses)

\begin{tabular}{|c|c|c|c|c|c|}
\hline Estimation & OLS & OLS & OLS & OLS & OLS \\
\hline$Y=$ varies by column & (1) & (2) & (3) & (4) & (5) \\
\hline$Y=$ & $\Delta \operatorname{Ln}(H S)$ & $\Delta \operatorname{Ln}(H S)$ & $\Delta \operatorname{Ln}(H S)$ & $\Delta \operatorname{Ln}(H R)$ & $\Delta \operatorname{Ln}(\tilde{A})$ \\
\hline$\Delta \operatorname{Ln}\left(H S^{*}\right)$ & $\begin{array}{l}0.997 \\
(.034)\end{array}$ & $\begin{array}{l}0.994 \\
(.036)\end{array}$ & $\begin{array}{l}1.001 \\
(.04)\end{array}$ & $\begin{array}{l}0.101 \\
(.023)\end{array}$ & $\begin{array}{l}0.001 \\
(.001)\end{array}$ \\
\hline Total Aid & & $\begin{array}{l}0.003 \\
(.005)\end{array}$ & & & \\
\hline School Tax & & $\begin{array}{r}-0.005 \\
(.002)\end{array}$ & $\begin{array}{r}-0.002 \\
(.002)\end{array}$ & $\begin{array}{l}0.001 \\
(.002)\end{array}$ & $\begin{array}{l}0.000 \\
(.000)\end{array}$ \\
\hline Population & & $\begin{array}{l}0.092 \\
(.068)\end{array}$ & $\begin{array}{l}0.091 \\
(.068)\end{array}$ & $\begin{array}{l}-0.104 \\
(.068)\end{array}$ & $\begin{array}{l}0.001 \\
(.000)\end{array}$ \\
\hline Levy Limit & & $\begin{array}{l}0.002 \\
(.003)\end{array}$ & $\begin{array}{l}0.002 \\
(.003)\end{array}$ & $\begin{array}{l}-0.006 \\
(.003)\end{array}$ & $\begin{array}{l}0.000 \\
(.000)\end{array}$ \\
\hline$\Delta \operatorname{Ln}\left(\right.$ Median $\left.H R^{*}\right)$ & & & $\begin{array}{c}-0.034 \\
(.060)\end{array}$ & $\begin{array}{l}1.102 \\
(.044)\end{array}$ & $\begin{array}{l}0.003 \\
(.001)\end{array}$ \\
\hline$\Delta \operatorname{Ln}\left(\tilde{A}^{*}\right)$ & & & $\begin{array}{l}0.187 \\
(.178)\end{array}$ & $\begin{array}{l}0.12 \\
(.14)\end{array}$ & $\begin{array}{l}1.067 \\
(.015)\end{array}$ \\
\hline First Differences & Yes & Yes & Yes & Yes & Yes \\
\hline $\mathrm{R}^{2}$ & .79 & .8 & .79 & .70 & .99 \\
\hline Observations & 439 & 439 & 439 & 439 & 439 \\
\hline Years in Sample & 2000-01 & 2000-01 & 2000-01 & $2000-2001$ & \\
\hline
\end{tabular}

Note: Robust standard errors are in parentheses. All variables, except the levy limit dummy, are in natural logs so that reported coefficients are elasticities. See the paper for details on the instrumental variable. The sample contains cities in Minnesota with population greater than or equal 500 from 1994 to 2003. 
Table 4:

Homestead Tax Share and Property Tax Revenue (Standard Errors in Parentheses)

\begin{tabular}{|c|c|c|c|c|c|c|}
\hline Estimation & $\begin{array}{c}2 \text { SLS } \\
\text { (1) }\end{array}$ & $\begin{array}{c}\text { 2SLS } \\
\text { (2) }\end{array}$ & $\begin{array}{c}\text { 2SLS } \\
\text { (3) }\end{array}$ & $\begin{array}{c}\text { 2SLS } \\
\text { (4) }\end{array}$ & $\begin{array}{c}2 \text { SLS } \\
\quad(5)\end{array}$ & $\begin{array}{c}2 \text { SLS } \\
(6)\end{array}$ \\
\hline $\begin{array}{l}\text { Instrument for } H S \\
\text { Instrument for } H R \& \tilde{A}\end{array}$ & $\begin{array}{l}\text { No } \\
\text { No }\end{array}$ & $\begin{array}{l}\text { Yes } \\
\text { No }\end{array}$ & $\begin{array}{l}\text { Yes } \\
\text { No }\end{array}$ & $\begin{array}{l}\text { Yes } \\
\text { Yes }\end{array}$ & $\begin{array}{l}\text { Yes } \\
\text { No }\end{array}$ & $\begin{array}{l}\text { Yes } \\
\text { No }\end{array}$ \\
\hline $\begin{array}{l}\text { HS: Homestead Tax Share } \\
\text { HR: Median Homestead Ratio }\end{array}$ & $\begin{array}{c}-0.258 \\
(.134)\end{array}$ & $\begin{array}{r}-1.040 \\
(.175)\end{array}$ & $\begin{array}{r}-1.063 \\
(.213)\end{array}$ & $\begin{array}{l}-0.794 \\
(.197) \\
-0.830 \\
(.321)\end{array}$ & $\begin{array}{r}-1.023 \\
(.211)\end{array}$ & $\begin{array}{c}-0.995 \\
(.207)\end{array}$ \\
\hline control variables: & & & & & & \\
\hline Total Aid & $\begin{array}{l}-0.034 \\
(.014)\end{array}$ & & $\begin{array}{l}-0.059 \\
(.023)\end{array}$ & & $\begin{array}{l}-0.028 \\
(.014)\end{array}$ & $\begin{array}{l}-0.039 \\
(.015)\end{array}$ \\
\hline$\tilde{A}$ : Adjusted Aid & & & & $\begin{array}{l}-2.340 \\
(1.007)\end{array}$ & & \\
\hline School Tax & $\begin{array}{l}0.018 \\
(.030)\end{array}$ & & $\begin{array}{l}-0.024 \\
(.029)\end{array}$ & $\begin{array}{l}-0.023 \\
(.030)\end{array}$ & $\begin{array}{l}-0.016 \\
(.023)\end{array}$ & $\begin{array}{l}-0.012 \\
(.022)\end{array}$ \\
\hline Population & $\begin{array}{l}-0.192 \\
(.200)\end{array}$ & & $\begin{array}{l}-0.468 \\
(.293)\end{array}$ & $\begin{array}{l}-0.601 \\
(.217)\end{array}$ & $\begin{array}{l}-0.918 \\
(.196)\end{array}$ & $\begin{array}{l}-0.727 \\
(.188)\end{array}$ \\
\hline Levy Limit & $\begin{array}{r}-0.012 \\
(.009)\end{array}$ & & $\begin{array}{r}-0.028 \\
(.025)\end{array}$ & $\begin{array}{c}-0.034 \\
(.025)\end{array}$ & $\begin{array}{r}-0.045 \\
(.015)\end{array}$ & $\begin{array}{r}-0.024 \\
(.014)\end{array}$ \\
\hline First Differences & Yes & Yes & Yes & Yes & Yes & No \\
\hline City Fixed Effects & $\mathrm{Yes}^{a}$ & $\mathrm{Yes}^{a}$ & $\mathrm{Yes}^{a}$ & $\mathrm{Yes}^{a}$ & No & Yes \\
\hline City Linear Trend & No & No & No & No & Yes & Yes \\
\hline $\mathrm{R}^{2}$ & - & - & - & - & - & - \\
\hline Observations & 439 & 439 & 439 & 439 & 1,317 & 1,756 \\
\hline Years in Sample & 1998-99 & 2000-01 & 2000-01 & 2000-01 & $1998-2001$ & $1998-2001$ \\
\hline
\end{tabular}

Note: Robust standard errors are in parentheses. All variables, except the levy limit dummy, are in natural logs so that reported coefficients are elasticities. See the paper for details on the instrumental variable. The sample contains cities in Minnesota with population greater than or equal 500 from 1994 to 2003.

$a$ : The regressions are in first differences and with only two years of data the results are identical to a fixed effects specification. 
Table 5:

Homestead Tax Share and Expenditures (Standard Errors in Parentheses)

\begin{tabular}{lcccc}
\hline \hline Estimation & 2 SLS & 2SLS & 2SLS & 2SLS \\
$Y=$ varies by column & $(1)$ & $(2)$ & $(3)$ & $(4)$ \\
$Y=$ & Prop Tax & Total Exp & Cur Exp & Cap Exp \\
\hline Instrument for HS & Yes & Yes & Yes & Yes \\
& & & & \\
HS: Homestead Tax Share & -1.023 & -1.163 & -0.169 & -2.386 \\
& $(.211)$ & $(.369)$ & $(.146)$ & $(1.272)$ \\
control variables: & & & & \\
Total Aid & -0.028 & 0.368 & 0.079 & 0.674 \\
& $(.014)$ & $(.048)$ & $(.02)$ & $(.118)$ \\
School Tax & -0.016 & -0.044 & -0.009 & -0.078 \\
& $(.023)$ & $(.024)$ & $(.012)$ & $(.086)$ \\
Population & -0.918 & -0.009 & -0.77 & 0.962 \\
& $(.196)$ & $(.359)$ & $(.116)$ & $(.951)$ \\
Levy Limit & -0.045 & -0.065 & 0.013 & -0.218 \\
& $(.015)$ & $(.044)$ & $(.022)$ & $(.136)$ \\
& & & & \\
First Differences & Yes & Yes & Yes & Yes \\
City Linear Trend & Yes & Yes & Yes & Yes \\
\hline R & - & - & - & - \\
Observations & 1,317 & 1,317 & 1,317 & 1,310 \\
Years in Sample & $1998-2001$ & $1998-2001$ & $1998-2001$ & $1998-2001$ \\
\hline \hline
\end{tabular}

Note: Robust standard errors are in parentheses. All variables, except the levy limit dummy, are in natural logs so that reported coefficients are elasticities. See the paper for details on the instrumental variable. The sample contains cities in Minnesota with population greater than or equal 500 from 1994 to 2003. 
Table 6:

Robustness Checks

(Standard Errors in Parentheses)

\begin{tabular}{|c|c|c|c|c|c|c|}
\hline Estimation & 2SLS & 2SLS & 2SLS & 2SLS & 2SLS & 2SLS \\
\hline Specification & \multicolumn{3}{|c|}{ Falsification Tests } & \multicolumn{2}{|c|}{ Long Differences } & Pop Weights \\
\hline$Y=$ varies by column & (1) & (2) & (3) & (4) & $(5)$ & (6) \\
\hline$Y=$ & Prop Tax & Cur Exp & Cap Exp & Prop Tax & Cap Exp & Prop Tax \\
\hline Instrument for $H S$ & Yes & Yes & Yes & Yes & Yes & Yes \\
\hline HS: Homestead Tax Share & $\begin{array}{l}0.006 \\
(.099)\end{array}$ & $\begin{array}{l}0.075 \\
(.124)\end{array}$ & $\begin{array}{c}-0.164 \\
(.906)\end{array}$ & $\begin{array}{c}-0.856 \\
(.191)\end{array}$ & $\begin{array}{l}-2.222 \\
(1.081)\end{array}$ & $\begin{array}{r}-1.205 \\
(.301)\end{array}$ \\
\hline control variables: & & & & & & \\
\hline Total Aid & $\begin{array}{l}-0.018 \\
(.015)\end{array}$ & $\begin{array}{l}-0.027 \\
(.022)\end{array}$ & $\begin{array}{l}-0.123 \\
(.197)\end{array}$ & $\begin{array}{l}-0.054 \\
(.024)\end{array}$ & $\begin{array}{l}0.992 \\
(.138)\end{array}$ & $\begin{array}{c}-0.231 \\
(.06)\end{array}$ \\
\hline School Tax & $\begin{array}{c}-0.001 \\
(.007)\end{array}$ & $\begin{array}{c}-0.005 \\
(.008)\end{array}$ & $\begin{array}{c}0.057 \\
(.1)\end{array}$ & $\begin{array}{r}-0.023 \\
(.033)\end{array}$ & $\begin{array}{c}-0.090 \\
(.127)\end{array}$ & $\begin{array}{l}-0.028 \\
(.036)\end{array}$ \\
\hline Population & $\begin{array}{l}0.079 \\
(.084)\end{array}$ & $\begin{array}{l}0.053 \\
(.165)\end{array}$ & $\begin{array}{c}-0.111 \\
(.445)\end{array}$ & $\begin{array}{c}-0.347 \\
(.14)\end{array}$ & $\begin{array}{l}0.181 \\
(.635)\end{array}$ & $\begin{array}{l}0.117 \\
(.221)\end{array}$ \\
\hline Levy Limit & $\begin{array}{l}0.034 \\
(.011)\end{array}$ & $\begin{array}{l}-0.008 \\
(.017)\end{array}$ & $\begin{array}{l}0.191 \\
(.109)\end{array}$ & $\begin{array}{l}0.030 \\
(.068)\end{array}$ & $\begin{array}{l}.0286 \\
(.386)\end{array}$ & $\begin{array}{l}-0.083 \\
(.028)\end{array}$ \\
\hline First Differences & Yes & Yes & Yes & Yes & Yes & Yes \\
\hline City Fixed Effects & No & No & No & Yes $^{a}$ & $\mathrm{Yes}^{a}$ & $\mathrm{Yes}^{a}$ \\
\hline City Linear Time Trend & No & No & No & No & No & No \\
\hline Notes & A & A & A & $\mathrm{B}$ & $\mathrm{B}$ & $\mathrm{C}$ \\
\hline$R^{2}$ & - & - & - & - & - & - \\
\hline Observations & 439 & 439 & 435 & 439 & 436 & 439 \\
\hline
\end{tabular}

Note: Robust standard errors are in parentheses. All variables, except the levy limit dummy, are in natural logs so that reported coefficients are elasticities. See the paper for details on the instrumental variable. The dependent variable varies by column. The sample contains cities in Minnesota with population greater than or equal 500 from 1994 to 2003.

$a$ : The regressions are in first differences and with only two years of data the results are identical to a fixed effects specification.

A: Falsification Tests: Dependent variable is the change from 1998-1999; independent variables measure the change from 2000-2001. B: Long Differences: All variables measure the change from 1998 to 2001. C: Main Specification, Weighted by Population: All variables measure the change from 2000 to 2001. 


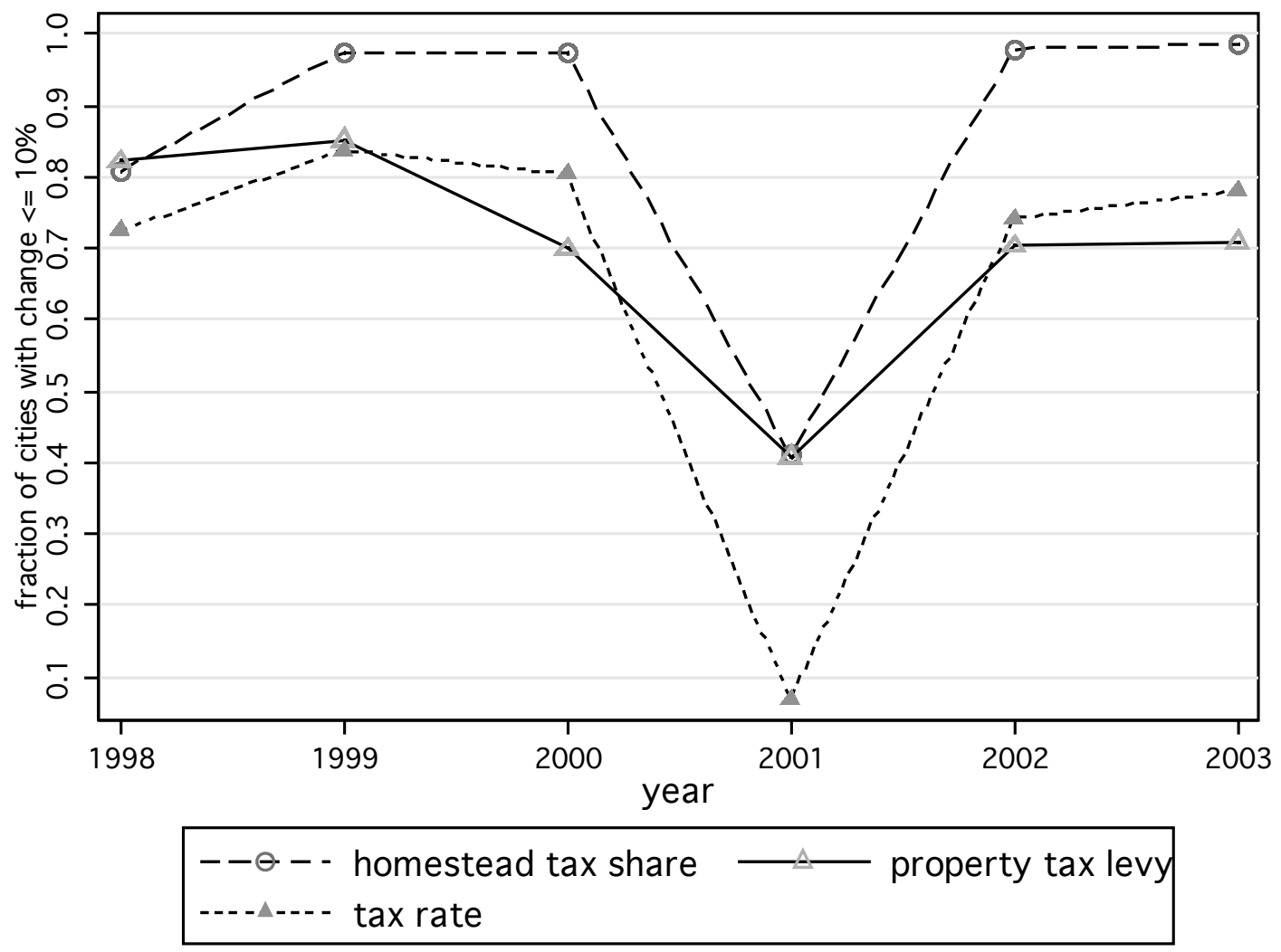

Figure 1: Policy Change Produces Within-City Variation Source: Authors' tabulations using MN Department of Revenue Data. Note: Sample contains 439 Minnesota cities. Homestead Tax Share is the percentage of tax base derived from homestead property. The property tax levy is the per-resident amount of property tax revenue requested by the government. The tax levy divided by the total tax base produces the tax rate. 


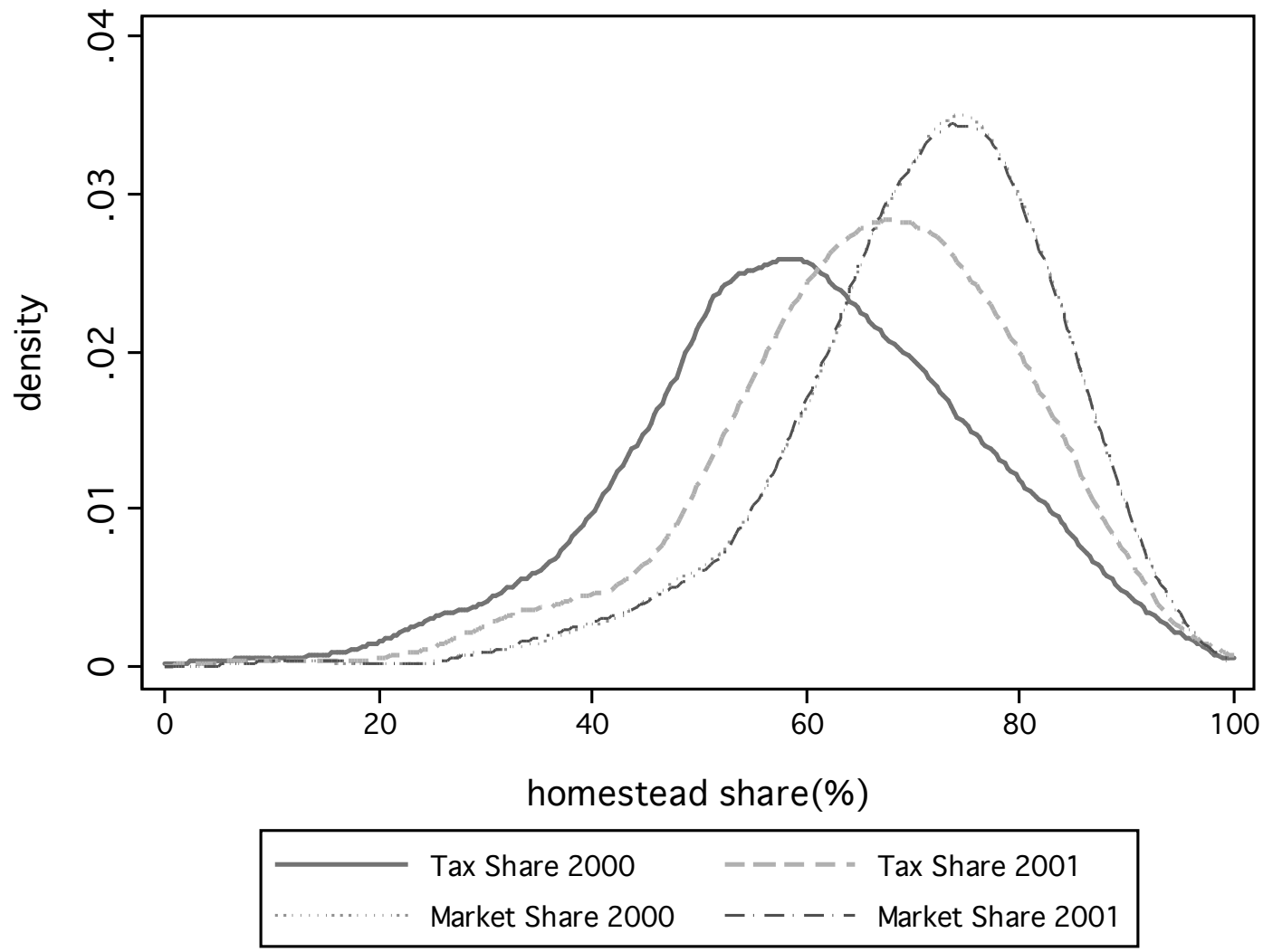

Figure 2: Homestead Tax Share and Homestead Market Share (2000 vs. 2001) Source: Authors' tabulations using MN Department of Revenue Data. Note: Sample contains 439 Minnesota cities. Homestead Tax Share is the percentage of tax base derived from homestead property. Homestead Market Share is the percentage of estimated total market value derived from homestead property. Market Share differs from Tax Share only because of institutional features common across the state. 


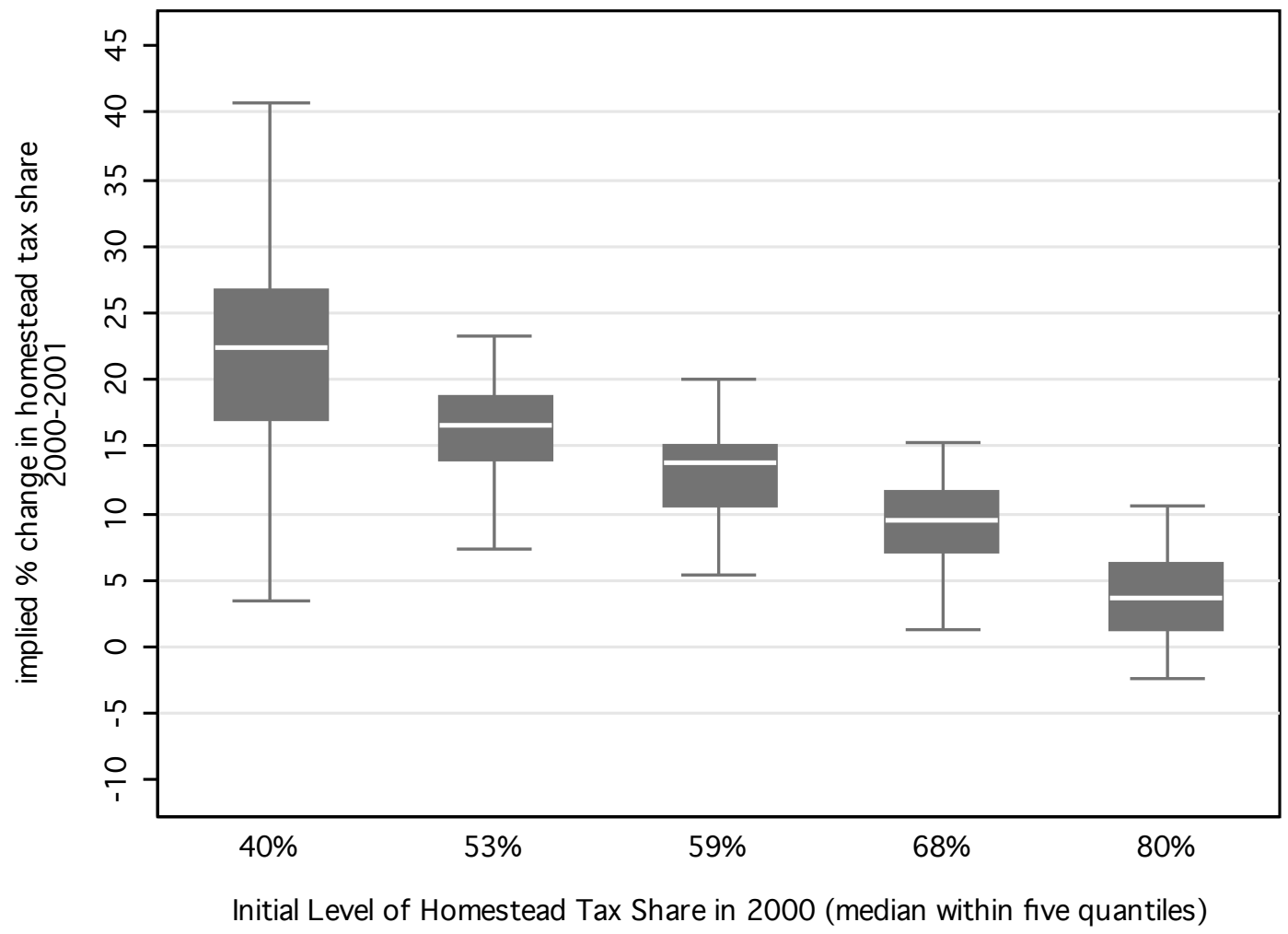

Figure 3: Implied Magnitudes of Policy Change: Heterogenous Treatment Source: Authors' tabulations using MN Department of Revenue Data. Note: Sample contains 439 Minnesota cities. Homestead Tax Share is the percentage of tax base derived from homestead property. The implied percentage change is the effect of the 2001 class rate changes, holding all market values constant at 2000 levels. The shaded area represents the inter-quartile range with the middle bar representing the median. 


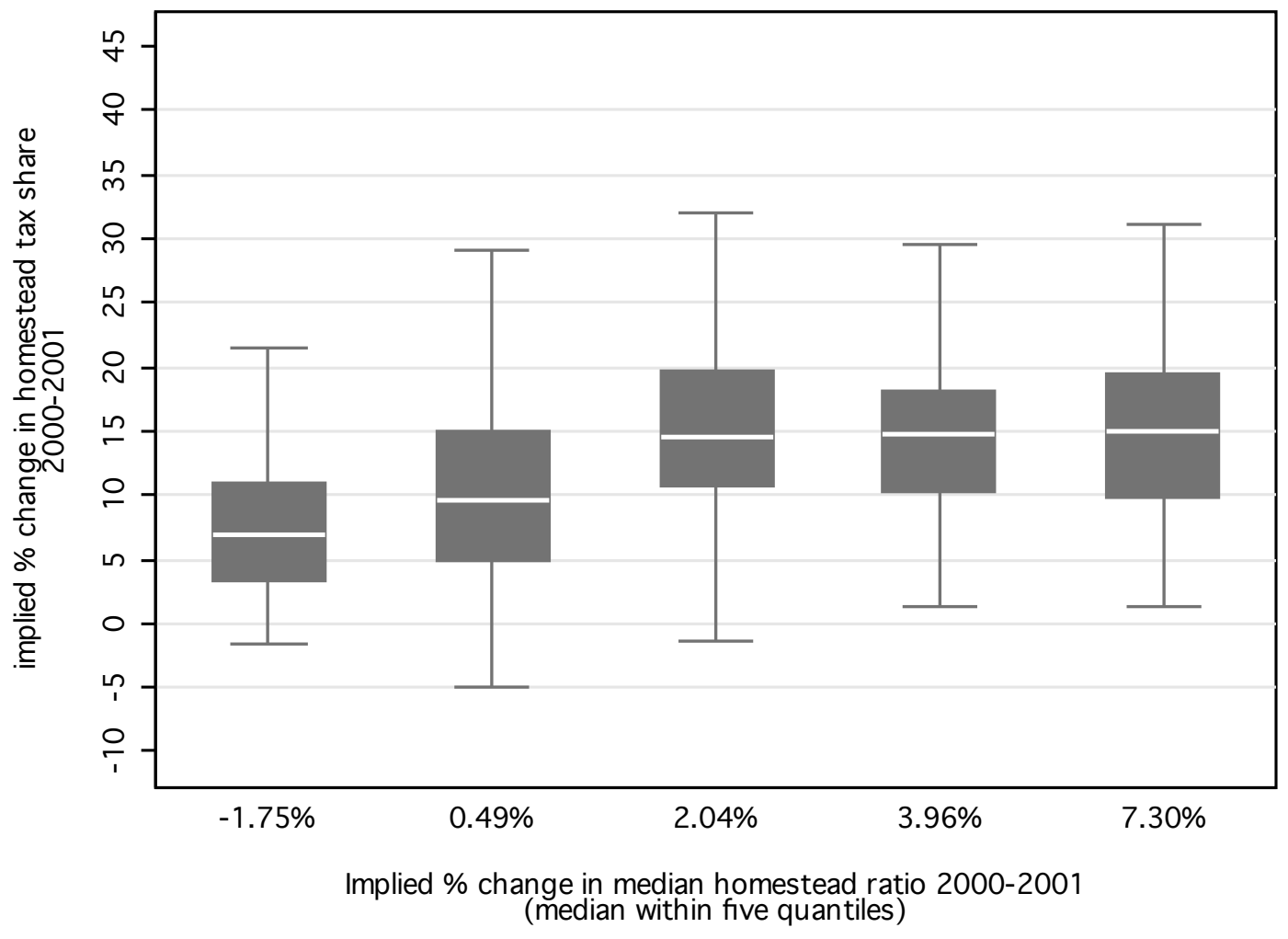

Figure 4: Different Treatments: Homestead Tax Share and Median Homestead Tax Ratio Source: Authors' tabulations using MN Department of Revenue Data. Note: Sample contains 439 Minnesota cities. Homestead Tax Share is the percentage of tax base derived from homestead property. Median Homestead Tax Ratio is the imputed ratio of median homestead taxable value to average homestead taxable value. The implied percentage change in both variables is the effect of the 2001 class rate changes, holding all market values constant at 2000 levels. The shaded area represents the inter-quartile range with the middle bar representing the median. 